\title{
Non-coding RNAs in polycystic ovary syndrome: a systematic review and meta- analysis
}

Liangshan $\mathrm{Mu}^{1+}$, Xiaoting Sun ${ }^{2+}$, Mixue Tu${ }^{1}$ and Dan Zhang ${ }^{1 *}$

\begin{abstract}
Background: Genetic, environmental and epigenetical factors may play important roles in the pathogenesis of polycystic ovary syndrome (PCOS), however the etiology of PCOS remains unclear. Studies indicated that non-coding RNAs (ncRNAs) were involved in the occurrence and development of PCOS. Thus, we aim to perform a systematic review and meta-analysis to investigate the presence and dysregulated expression of ncRNAs in human PCOS.

Methods: We searched in PubMed, Medline, Web of Science and Embase until July 2019 and summarized all eligible publications focusing on microRNAs (miRNAs), long non-coding RNAs (IncRNAs), circular RNAs (circRNAs) and small interfering RNAs (siRNAs) in PCOS.

Results: Sixty-seven articles were included in our systematic review and 9 articles were included in meta-analysis. There is little overlap between studies when comparing miRNA profiles. Sensitivity analysis showed that the expression of miR-93 was upregulated in PCOS patients (WMD 0.75, $P<0.00001$ ), without heterogeneity among remaining studies $\left(I^{2}=0 \%\right)$.

Conclusion: A large number of ncRNAs with altered levels were observed in plasma, serum, follicular fluid, granulosa cells or other issues from PCOS patients. Aberrant ncRNAs expression in PCOS may lead to aberrant steroidogenesis, adipocyte dysfunction, altered ovarian cell proliferation and/or apoptosis and have the potential to be used as diagnostic biomarkers.
\end{abstract}

Keywords: Polycystic ovary syndrome, Non-coding RNA, microRNA, Long non-coding RNA, circRNA

\section{Background}

Polycystic ovary syndrome (PCOS) is a common, multifactorial endocrine and metabolic disorder that have been estimated to affect approximately 5 to $20 \%$ of reproductive-aged women [1,2]. All existing diagnostic criteria for PCOS are based on endocrinological and reproductive characteristics, including polycystic ovarian

\footnotetext{
* Correspondence: zhangdan@zju.edu.cn

${ }^{+}$Liangshan Mu and Xiaoting Sun contributed equally to this work.

${ }^{1}$ Key Laboratory of Reproductive Genetics (Ministry of Education) and Department of Reproductive Endocrinology, Women's Hospital, Zhejiang University School of Medicine, Hangzhou, Zhejiang 310006, People's Republic of China

Full list of author information is available at the end of the article
}

morphology, anovulation and clinical and/or biochemical hyperandrogenism with the exclusion of other adrenal, pituitary or androgenic disorders [3]. In addition to association with infertility and increased risk of pregnancy complications, a considerable portion of patients with PCOS are also characterized by obesity, hirsutism, insulin resistance (IR) and increased risk of type 2 diabetes mellitus (T2DM), dyslipidemia, hypertension, cardiovascular disease and endometrial cancer [4, 5]. Although some studies suggested that genetic, environmental and epigenetical factors may play important roles in the pathogenesis of PCOS [6], the etiology of PCOS remains unclear.

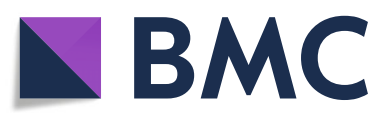

(c) The Author(s). 2021 Open Access This article is licensed under a Creative Commons Attribution 4.0 International License, which permits use, sharing, adaptation, distribution and reproduction in any medium or format, as long as you give appropriate credit to the original author(s) and the source, provide a link to the Creative Commons licence, and indicate if changes were made. The images or other third party material in this article are included in the article's Creative Commons licence, unless indicated otherwise in a credit line to the material. If material is not included in the article's Creative Commons licence and your intended use is not permitted by statutory regulation or exceeds the permitted use, you will need to obtain permission directly from the copyright holder. To view a copy of this licence, visit http://creativecommons.org/licenses/by/4.0/. The Creative Commons Public Domain Dedication waiver (http://creativecommons.org/publicdomain/zero/1.0/) applies to the data made available in this article, unless otherwise stated in a credit line to the data. 
Non-coding RNAs (ncRNAs) are functional RNAs which are not coded for protein production but serve important regulatory role in numerous biological processes [7]. According to the nucleotides length threshold of 200 nucleotides, ncRNAs are classified into small ncRNAs (sncRNAs) and long ncRNAs (lncRNAs) [8, 9]. SncRNAs were categorized into different subgroups, including microRNAs (miRNAs), small nuclear RNAs (snRNAs), small nucleolar RNAs (snoRNAs), small interfering RNAs (siRNAs), and PIMI-interacting RNAs (piRNAs) [10-12]. Circular RNAs (circRNAs), a subgroup of ncRNAs, are named for the covalently closed circular structures which do not have a canonical $5^{\prime}$ cap and $3^{\prime}$ terminal poly A tail [13]. Ribosomal RNAs (rRNAs) and transfer RNAs (tRNAs) are also well-known ncRNAs which are highly abundant and serve key functions in RNA translation. NcRNAs regulate expression of target genes at post-transcriptional level which facilitate the occurrence and development of diseases [14]. Recently, some researches indicated that ncRNAs were involved in occurrence and development of PCOS. There were significantly differential expressions of sncRNAs in serum, granulosa cells (GCs), follicular fluid (FF) and other tissues between PCOS patients and PCOS-free population $[15,16]$. Therefore, analysis of the differential expression of ncRNAs in patients with PCOS may have the possibility of be used as diagnostic biomarkers and therapeutic targets [17].

The aim of this systematic review and meta-analysis was to investigate the presence and dysregulated expression of ncRNAs in human PCOS and discuss the potential roles of these different types of ncRNAs in the pathophysiology of PCOS. Understanding the underlying molecular mechanisms of this syndrome may help to improve effective diagnosis and treatment.

\section{Materials and methods}

Our systematic literature search adhered to the standard criteria Preferred Reporting Items for Systematic Reviews and Meta-Analysis (PRISMA) [18, 19].

\section{Search strategy}

A comprehensive literature search was conducted in various electronic databases, including PubMed, Medline, Web of Science and Embase. Each of the terms "non-coding RNA", "noncoding RNA", "ncRNA", "miRNA", "microRNA", "siRNA", "snoRNA", "circRNA" and "IncRNA" was combined (using "AND") with each of the following terms "Polycystic ovary syndrome", "PCOS", "stein-leventhal" as well as with "ovary sclerocystic" and "ovary degeneration". All articles published before July 2019 were considered for eligibility.

\section{Eligible studies and data extraction}

Eligible studies had to meet the following criteria: 1) case-control or cohort studies; 2) original articles evaluated the expression of ncRNAs between PCOS patients and health controls; 3) reported mean expression level and fold changes (FC) of included ncRNAs. Reviews, abstracts, animal models, articles not in English or looking at drugs regulating ncRNAs in PCOS were excluded.

From eligible articles presenting original data, we extracted the information including name of the first author, year of publication, type of the samples detected, number of patients with PCOS and controls, age, body mass index (BMI) and dysregulated ncRNAs identified in PCOS.

\section{Quality assessment}

Included studies were assessed by the Newcastle-Ottawa Scale (NOS) [20]. This scale evaluated three categories, including Selection (case definition, representativeness, control selection and control definition), Comparability of cases and controls, and Exposure (ascertainment of exposure, same method of ascertainment for cases and controls, and non-response rate). For each item within the Selection and Exposure categories, a study can be given a maximum of one star, while Comparability can be awarded a maximum of two stars. Getting five or more stars is considered a high-quality study [21].

\section{Statistical analysis}

Among studies reporting relative FC of miRNA expression, a meta-analysis was established. Outcomes were reported as weighted mean differences (WMD). A random effect model was applied regardless of heterogeneity. The heterogeneity was calculated with both the Cochran's Q statistic test and the $\mathrm{I}^{2}$ test. $\mathrm{I}^{2}>50 \%$ indicated significant heterogeneity. If there was significant heterogeneity, we looked for potential sources of heterogeneity. For example, the results of one study were completely beyond the scope of the others, we looked for possible reasons to explain the difference. Then excluded from that study and carried out a sensitivity analysis. A subgroup analysis based on the type of sample source was also performed. All analyses were performed using the Review Manager 5.4.

\section{Results}

\section{Search results}

In total, we retrieved 623 articles. After exclusion of 283 multiplicate, 340 different records remained. Then, after screening based on the abstract or title, 270 studies were excluded for the following reasons: non-primary study on PCOS, reviews, abstracts, non-human articles. Next, full texts of the 70 remaining articles were examined for eligibility. Two studies were excluded for non-English 
publication. One study focusing on the drugs regulating miRNAs to relieve the symptoms of PCOS was also excluded. Finally, we included 67 articles in this review. A flow diagram of this literature systematic search process is presented in Fig. 1.

The details for the risk of bias for case-control studies are shown in Supplemental Table 1. All included studies scored 6 or more stars on the modified NOS.

We summarized all relevant published literature focusing on miRNAs, long ncRNAs (lncRNAs), circular RNAs and small interfering RNAs (siRNAs) in PCOS from human research. The results generally show limited concordance among these studies, which reflected the heterogeneity of those studies in specimen collection, selection of patients and controls, bioinformatic analysis and normalization of methods.

\section{MicroRNAs}

MicroRNAs (miRNAs) are endogenous, small (composed of 20-24 nucleotides), single-stranded RNAs that were first identified in 1993 by Lee and colleagues [22]. MiRNAs regulate post-transcriptional gene expression through degradation of target messenger RNAs (mRNAs) or translational repression [11]. They negatively regulate expression of target genes by binding with the $3^{\prime}$-untranslated region ( $3^{\prime}$-UTRs) of corresponding mRNAs [10]. MiRNAs are involved in numerous important cellular processes, including cell proliferation, differentiation, apoptosis, tumorigenesis and development $[22,23]$.

Multiple studies have shown that expression of miRNAs were altered in serum, whole blood, adipose tissue, GCs, FF, and other reproductive tissues between PCOS patients and PCOS-free population [24-27]. In patients with PCOS, differentially expressed miRNAs are involved in a variety of signal pathways, including amino acid metabolism, hormone regulation, cell differentiation, and so on [13, 28]. In consequence, abnormal expression of miRNAs may provide new insight into investigating mechanisms of the pathogenesis of PCOS

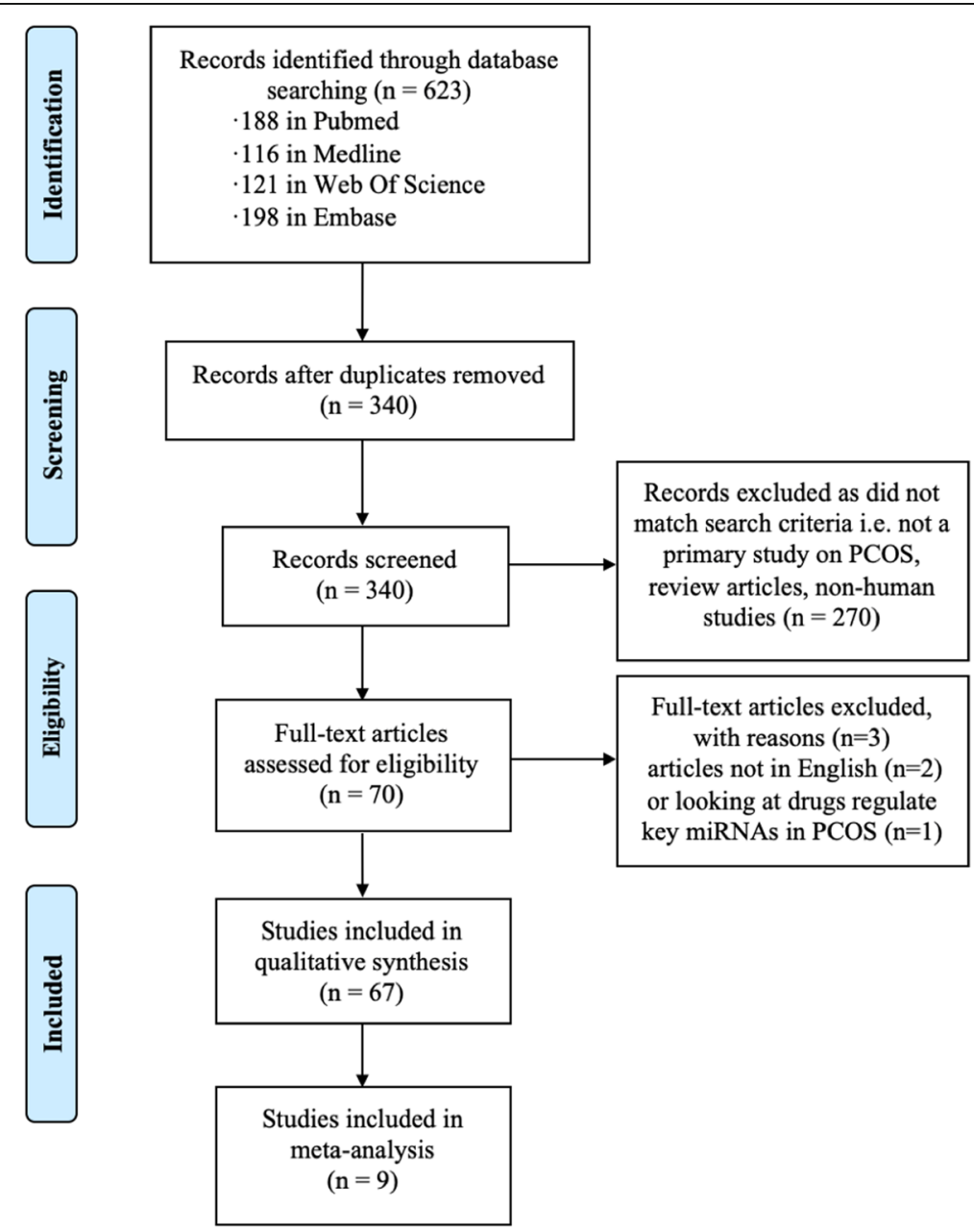

Fig. 1 PRISMA flow methodology for selection of relevant studies. Abbreviations: PCOS, polycystic ovary syndrome 
and exploring the potential biomarkers of disease progression.

\section{Serum/plasma miRNAs in PCOS}

MicroRNAs are stable, resistant to ribozyme activity and easily to be detected in serum. Therefore, miRNAs can serve as potential non-invasive biomarkers for PCOS [29]. Seventeen studies have shown that miRNAs are altered in whole blood, serum or plasma samples in women with and without PCOS [15, 24, 30-44] (Table 1). The miRNAs identified showed little consistency between these studies, which are probably due to the considerable heterogeneity of specimen collection, experimental design, bioinformatic assessment of the studies and standardized methods.

Long et al. [24] evaluated expression of serum miRNAs using miRNA arrays in women with PCOS $(n=5)$ and age-matched controls $(n=5)$. Eight miRNAs (miR16, miR-19a, miR-24, miR-30c, miR-106b, miR-146a, miR-186, miR-222 and miR-320) were upregulated in serum from PCOS women, while miR-320 was downregulated in the serum from PCOS women. However, quantitative polymerase chain reaction (qPCR) in women with PCOS $(n=68)$ and without PCOS $(n=68)$ confirmed that three miRNAs (miR-30c, miR-146a and miR-222) were significantly upregulated in PCOS patients. Sensitivity and specificity analysis revealed that the combination of miR-30c, miR-146a and miR-222 was suggested as potential diagnostic markers. A larger study [38], contrasting women with $(n=205)$ and without $(n=205)$ PCOS, showed that the miR-146a rs2910164 and miR-222 rs2858060 polymorphisms are significantly associated with increased risk of PCOS. Ebrahimi et al. [40] also found that the miR-146a rs2910164 polymorphism significantly differed between PCOS $(n=180)$ and healthy controls $(n=192)$.

\section{Follicular fluid (FF) miRNAs in PCOS}

Ovarian FF not only serves as an important microenvironment for the development of the oocyte but also contains important regulators such as ovarian cell secretions, hormones and blood plasma components that act a vital role in oocyte maturation [15]. Ten studies suggested that expression of miRNAs in FF from PCOS women was different from that of healthy controls [16, 25, 42, 45-48, 50-52] (Table 1). There is little overlap between these studies when comparing the miRNA profiles.

Roth et al. [45] found that 29 miRNAs were differentially expressed between the PCOS group $(n=12)$ and healthy controls $(n=12)$. Among these miRNAs, the expression of 5 miRNAs (miR-9, miR-18b, miR-32, miR$34 \mathrm{c}$ and 135a) showed significant upregulation in FF from PCOS women. Further pathway analysis revealed possible target genes involved in steroid synthesis, carbohydrate metabolism and insulin regulation [17, 74]. These target genes identified exert functions related to PCOS phenotypes.

Sang et al. [25] identified that over 100 miRNAs were significantly differentially expressed in FF from women with PCOS $(n=24)$ and non-PCOS controls $(n=24)$ undergoing intracytoplasmic sperm injection (ICSI) treatment. They found that the expression level of miR320 was downregulated in PCOS patients compared to the healthy controls. Furthermore, another study conducted by Yin et al. [46] using FF and GCs from women with $(n=19)$ or without $(n=15)$ PCOS suggested that the expression of miR-320 was upregulated in FF and GCs from women with PCOS compared to the controls. This is contradictory to the results of study by Sang et al. The miRNA profile of FF variability between studies could be attributed to study populations, heterogenic nature of PCOS, differences in the control groups or different methods. Thus, larger well-powered studies are needed to identify candidate miRNAs which are most relevant to PCOS.

\section{Granulosa cells/ cumulus cells miRNAs in PCOS}

Granulosa cells (GCs) are vital for oocyte growth and maturation. Dysfunction of GCs may contribute to abnormal folliculogenesis and unbalanced hormone production in patients with PCOS $[19,49]$. Cumulus cells are a unique subset of GCs which interact with the oocyte directly and are essential for regulation of oocyte metabolism [75]. To date, 19 studies have examined miRNAs in either GCs or cumulus cells taken from women with and without PCOS [16, 27, 46, 53-68] (Table 1). Collectively, these data indicate that distinct miRNA profiles do indeed exist in GCs / cumulus cells between PCOS group and healthy controls. Potential pathogenic miRNAs play a multi-faceted role in hormone regulation, cellular proliferation and angiogenesis.

Amongst these differentially expressed miRNAs, miR$513 \mathrm{~b}$ has showed significant upregulation in cumulus cells of PCOS patients in three studies [54-56]. In addition, upregulation of miR-423-3p in cumulus cells of PCOS women was reported by two studies $[55,56]$. MiR-509-3p, a miRNA identified in Huang's [56] and Liu's [54], also shown up-regulated expression in cumulus cells from PCOS women.

In GCs from women with PCOS, miR-93 showed significant upregulation as reported by two studies [16, 27], while miR-145 was downregulated in another two studies compared to control group [42, 57].

\section{Other tissues miRNAs in PCOS}

Eight studies have revealed that expression of miRNAs was altered in other samples of PCOS population, including blastocysts [69], adipose tissue [26, 70], ovarian 
Table 1 Studies evaluating altered miRNA expression in women with and without PCOS

\begin{tabular}{|c|c|c|c|c|c|}
\hline Study & $\begin{array}{l}\text { Detected in } \\
\text { tissue/cell }\end{array}$ & No. of PCOS and control & $\begin{array}{l}\text { Age of PCOS/ } \\
\text { control (years) }\end{array}$ & $\begin{array}{l}\text { BMI of PCOS/ } \\
\text { control }(\mathrm{m} / \mathrm{kg} 2)\end{array}$ & Dysregulated miRNAs \\
\hline $\begin{array}{l}\text { Murri et al. } \\
2013 \text { [15] }\end{array}$ & Whole blood & $\begin{array}{l}12 \text { PCOS vs } 12 \text { healthy } \\
\text { controls woman vs } 12 \\
\text { healthy men }\end{array}$ & $\begin{array}{l}\text { Lean: } \\
27 \pm 4 / 29 \pm 3 \\
\text { Obese: } \\
27 \pm 2 / 29 \pm 7\end{array}$ & $\begin{array}{l}\text { Lean: } \\
22 \pm 2 / 22 \pm 2 \\
\text { Obese: } \\
39 \pm 9 / 27 \pm 6\end{array}$ & $\begin{array}{l}\text { Upregulated: } \\
\text { miR-21,27b, } 103 \text { and } 155\end{array}$ \\
\hline $\begin{array}{l}\text { Long et al. } \\
2014 \text { [24] }\end{array}$ & Serum & 68 PCOS vs 68 controls & $\begin{array}{l}26.6 \pm 2.8 / 27.9 \pm \\
3.4\end{array}$ & $\begin{array}{l}25.9 \pm 3.4 / 22.4 \pm \\
2.1\end{array}$ & $\begin{array}{l}\text { Upregulated: } \\
\text { miR-222, 146a and 30c }\end{array}$ \\
\hline $\begin{array}{l}\text { Liyan Jiang } \\
\text { et al. } 2015 \\
\text { [31] }\end{array}$ & Serum & 30 PCOS vs 30 controls & $\begin{array}{l}27.5 \pm 3.2 / 28.1 \pm \\
4.1\end{array}$ & $\begin{array}{l}25.8 \pm 2.1 / 22.3 \pm \\
1.5\end{array}$ & $\begin{array}{l}\text { Upregulated: } \\
\text { miR21,222,16,19a,30c, } \\
146 a, 24 \text { and } 186\end{array}$ \\
\hline $\begin{array}{l}\text { Ding et al. } \\
2015 \text { [30] }\end{array}$ & Serum & 18 PCOS vs 18 controls & $\begin{array}{l}28.3 \pm 5.6 / 29.1 \pm \\
4.8\end{array}$ & $\begin{array}{l}31.5 \pm 4.1 / 22.7 \pm \\
3.2\end{array}$ & $\begin{array}{l}\text { Upregulated: } \\
\text { miR-5706, let-7i-3 pm, 4463, } 3665 \text { and } 638 \\
\text { Downregulated: } \\
\text { miR-124-3p, 128, 29a-3p and let-7c }\end{array}$ \\
\hline $\begin{array}{l}\text { Sathyapalan } \\
\text { et al. } 2015 \\
\text { [32] }\end{array}$ & Plasma & 25 PCOS vs 25 controls & $\begin{array}{l}32.1 \pm 9 / 32.2 \pm \\
7.7\end{array}$ & $\begin{array}{l}28.8 \pm 5.4 / 27.1 \pm \\
5.8\end{array}$ & $\begin{array}{l}\text { Upregulated: } \\
\text { miR-93 and } 223\end{array}$ \\
\hline $\begin{array}{l}\text { Song et al. } \\
2015 \text { [33] }\end{array}$ & Serum & 67 PCOS vs 67 controls & $\begin{array}{l}26.7 \pm 2.7 / 27.6 \pm \\
3.3\end{array}$ & $\begin{array}{l}24.8 \pm 3.3 / 21.9 \pm \\
2.2\end{array}$ & $\begin{array}{l}\text { Downregulated: } \\
\text { miR-592,124-3p, 128, 29-3p, 16, 106b, 19a, 24, 186, } \\
\text { let-7c and } 1228\end{array}$ \\
\hline $\begin{array}{l}\text { Zhao et al. } \\
2015 \text { [34] }\end{array}$ & Serum & 30 PCOS vs 70 controls & $\begin{array}{l}27.70 \pm 3.44 / \\
27.93 \pm 3.84\end{array}$ & $\begin{array}{l}24.39 \pm 3.67 / \\
21.87 \pm 2.93\end{array}$ & $\begin{array}{l}\text { Upregulated: } \\
\text { miR-146a, 30c and } 191 \\
\text { Downregulated: } \\
\text { miR-16, 223, 212, } 451 \text { and } 92 \text { a }\end{array}$ \\
\hline $\begin{array}{l}\text { Song et al. } \\
2016 \text { [36] }\end{array}$ & Serum & 21 PCOS vs 21 controls & $23 \pm 4 / 24 \pm 6$ & $\begin{array}{l}21.7 \pm 2.3 / \\
22.2 \pm 2.7\end{array}$ & $\begin{array}{l}\text { Downregulated: } \\
\text { miR-4522, 324-3p, and 6767-5p }\end{array}$ \\
\hline $\begin{array}{l}\text { Jiang et al. } \\
2016 \text { [35] }\end{array}$ & Serum & 30 PCOS vs 30 controls & $\begin{array}{l}27.16 \pm 3.56 / \\
27.98 \pm 3.66\end{array}$ & $\begin{array}{l}22.24 \pm 3.87 / \\
20.46 \pm 2.44\end{array}$ & $\begin{array}{l}\text { Upregulated: } \\
\text { miR-122, 194, and 193b } \\
\text { Downregulated: } \\
\text { miR-199b-5p }\end{array}$ \\
\hline $\begin{array}{l}\text { Xiong et al. } \\
2017 \text { [39] }\end{array}$ & Serum & 18 PCOS vs 30 controls & $\begin{array}{l}25.8 \pm 4.5 / 25.5 \pm \\
2.3\end{array}$ & $\begin{array}{l}23.96 \pm 4.44 / \\
20.99 \pm 3.31\end{array}$ & $\begin{array}{l}\text { Downregulated: } \\
\text { miR-23a and } 23 \mathrm{~b}\end{array}$ \\
\hline $\begin{array}{l}\text { Hosseini } \\
\text { et al. } 2017 \\
{[38]}\end{array}$ & Plasma & 205 PCOS vs 205 controls & $\begin{array}{l}31.2 \pm 5.5 / 28.5 \pm \\
5\end{array}$ & $\begin{array}{l}26.5 \pm 5 / 25.1 \pm \\
4.6\end{array}$ & $\begin{array}{l}\text { Upregulated: } \\
\text { miR-146a and } 222\end{array}$ \\
\hline $\begin{array}{l}\text { Eisenberg } \\
\text { et al. } 2017 \\
\text { [37] }\end{array}$ & Serum & 18 PCOS vs 15 controls & $\begin{array}{l}26.9 \pm 4.3 / 26.8 \pm \\
4.7\end{array}$ & $\begin{array}{l}29.3 \pm 7.1 / 23.6 \pm \\
3.3\end{array}$ & $\begin{array}{l}\text { Upregulated: } \\
\text { miR-200b and } 429\end{array}$ \\
\hline $\begin{array}{l}\text { Ebrahimi } \\
\text { et al. } 2018 \\
\text { [40] }\end{array}$ & Whole blood & 180 PCOS vs 192 controls & $\begin{array}{l}26.8 \pm 5.5 / 27.0 \pm \\
4.38\end{array}$ & $\begin{array}{l}23.3 \pm 3.6 / \\
22.92 \pm 2.86\end{array}$ & Upregulated: miR-146a \\
\hline $\begin{array}{l}\text { Naji et al. } \\
2018 \text { [42] }\end{array}$ & $\begin{array}{l}\text { Serum, } \\
\text { granulosa- } \\
\text { lutein cells, } \\
\text { follicular fluid }\end{array}$ & 20 PCOS vs 21 controls & $\begin{array}{l}29.25 \pm 0.84 / \\
28.42 \pm 0.91\end{array}$ & $\begin{array}{l}26.48 \pm 0.85 / \\
24.58 \pm 0.85\end{array}$ & $\begin{array}{l}\text { Upregulated in follicular fluid: } \\
\text { miR-182 } \\
\text { Downregulated in granulosa-lutein cells: miR-145 } \\
\text { and } 182\end{array}$ \\
\hline $\begin{array}{l}\text { Murri et al. } \\
2018 \text { [41] }\end{array}$ & Serum & 12 PCOS vs 11 controls & $\begin{array}{l}\text { Lean: } 27 \pm 4 / \\
28 \pm 3 \\
\text { Obese: } \\
27 \pm 2 / 31 \pm 6\end{array}$ & $\begin{array}{l}\text { Lean: } \\
22 \pm 2 / 22 \pm 2 \\
\text { Obese: } \\
39 \pm 9 / 37 \pm 3\end{array}$ & $\begin{array}{l}\text { Upregulated: } \\
\text { miR-34c-5p and 548d-3p } \\
\text { Downregulated: } \\
\text { miR-26a-5p, 30c-5p, } 107 \text { and 199a-3p }\end{array}$ \\
\hline $\begin{array}{l}\text { Nanda et al. } \\
2019 \text { [43] }\end{array}$ & Serum & 20 PCOS vs 20 controls & $\begin{array}{l}28.35 \pm 7.45 / \\
25.15 \pm 4.12\end{array}$ & $\begin{array}{l}32.16 \pm 4.93 / \\
22.02 \pm 2.64\end{array}$ & $\begin{array}{l}\text { Upregulated: } \\
\text { miR-122, 194, and 193b } \\
\text { Downregulated: } \\
\text { miR-199b-5p }\end{array}$ \\
\hline $\begin{array}{l}\text { Rashad et al. } \\
2019 \text { [44] }\end{array}$ & Serum & 60 PCOS vs 40 controls & $\begin{array}{l}31.95 \pm 7.42 / \\
32.38 \pm 7.68\end{array}$ & $\begin{array}{l}33.2 \pm 5.73 / \\
24.9 \pm 2.48\end{array}$ & Downregulated: miR-320 \\
\hline $\begin{array}{l}\text { Sang et al. } \\
2013 \text { [25] }\end{array}$ & Follicular fluid & 24 PCOS vs 24 controls & $\begin{array}{l}29.09 \pm 0.70 / \\
30.83 \pm 0.90\end{array}$ & $\begin{array}{l}23.38 \pm 0.59 / \\
21.95 \pm 0.51\end{array}$ & $\begin{array}{l}\text { Downregulated: } \\
\text { miR-132 and } 320\end{array}$ \\
\hline Roth et al. & Follicular fluid & 12 PCOS vs 12 controls & $33.1 \pm 4.4 / 27.1 \pm$ & $25.6 \pm 6.3 / 23.8 \pm$ & Upregulated: \\
\hline
\end{tabular}


Table 1 Studies evaluating altered miRNA expression in women with and without PCOS (Continued)

\begin{tabular}{|c|c|c|c|c|c|}
\hline Study & $\begin{array}{l}\text { Detected in } \\
\text { tissue/cell }\end{array}$ & No. of PCOS and control & $\begin{array}{l}\text { Age of PCOS/ } \\
\text { control (years) }\end{array}$ & $\begin{array}{l}\text { BMI of PCOS/ } \\
\text { control }(\mathrm{m} / \mathrm{kg} 2)\end{array}$ & Dysregulated miRNAs \\
\hline 2014 [45] & & & 3.6 & 2.9 & miR-32, 34c, 135a, 18b, and 9 \\
\hline $\begin{array}{l}\text { Yin et al. } \\
2014 \text { [46] }\end{array}$ & $\begin{array}{l}\text { Follicular fluid, } \\
\text { granulosa cells }\end{array}$ & 19 PCOS vs 15 controls & $20-40 / 20-40$ & NA/NA & $\begin{array}{l}\text { Upregulated: } \\
\text { miR-320 and miR-383 }\end{array}$ \\
\hline $\begin{array}{l}\text { Scalici et al. } \\
2016[47]\end{array}$ & Follicular fluid & 30 PCOS vs 91 controls & $\begin{array}{l}33.1 \pm 3.8 / 34.3 \pm \\
5.1\end{array}$ & $\begin{array}{l}25.4 \pm 5.3 / \\
22.8 \pm 3.7\end{array}$ & $\begin{array}{l}\text { Upregulated: miR-30a } \\
\text { Downregulated: } \\
\text { miR-140 and let-7b }\end{array}$ \\
\hline $\begin{array}{l}\text { Sorensen } \\
\text { et al. } 2016 \\
\text { [48] }\end{array}$ & Follicular fluid & 49 PCOS vs 21 controls & $\begin{array}{l}28.1 \pm 4.3 / 27.8 \pm \\
3.8\end{array}$ & $\begin{array}{l}25.7 \pm 5.1 / \\
24.2 \pm 3.8\end{array}$ & $\begin{array}{l}\text { Upregulated: } \\
\text { miR-518f-3p } \\
\text { Downregulated: } \\
\text { miR-24-3p, 29a, 151-3p and 574-3p }\end{array}$ \\
\hline $\begin{array}{l}\text { Naji et al. } \\
2017 \text { [49] }\end{array}$ & $\begin{array}{l}\text { Follicular fluid, } \\
\text { granulosa cells }\end{array}$ & $\begin{array}{l}19 \text { Hyper-androgenic PCOS } \\
\text { vs } 22 \text { normo-androgenic } \\
\text { PCOS }\end{array}$ & $\begin{array}{l}29 \pm 0.66 / \\
28.89 \pm 1.07\end{array}$ & $\begin{array}{l}27.02 \pm 0.97 / \\
25.94 \pm 0.75\end{array}$ & $\begin{array}{l}\text { Upregulated in granulosa cells: miR-93 } \\
\text { Downregulated in follicular fluid: } \\
\text { miR-93 and } 21\end{array}$ \\
\hline $\begin{array}{l}\text { Xue et al. } \\
2018[50]\end{array}$ & Follicular fluid & 3 PCOS vs 3 controls & $\begin{array}{l}29,36,38 / 30,31 \\
36\end{array}$ & $\begin{array}{l}21.51,22.13 \\
20.22 / 21.86 \\
21.14,20.94\end{array}$ & $\begin{array}{l}\text { Upregulated: } \\
\text { miR-200a-3p, 10b-3p, 200b-3p,29c-3p, 99a-3p and } \\
\text { 125a-5p Downregulated: } \\
\text { miR-105-3p }\end{array}$ \\
\hline $\begin{array}{l}\text { Yao et al. } \\
2018[51]\end{array}$ & Follicular fluid & 55 PCOS vs 51 controls & $\begin{array}{l}28.13 \pm 0.41 / \\
27.37 \pm 0.46\end{array}$ & $\begin{array}{l}23.25 \pm 0.45 / \\
21.62 \pm 0.38\end{array}$ & $\begin{array}{l}\text { Downregulated: } \\
\text { miR-335-5p }\end{array}$ \\
\hline $\begin{array}{l}\text { Zhang et al. } \\
2018 \text { [52] }\end{array}$ & Follicular fluid & 20 PCOS vs 20 controls & $N A / N A$ & NA/ NA & Upregulated: miR-873-5p \\
\hline $\begin{array}{l}\text { Linlin Jiang } \\
\text { et al. } 2015 \\
{[27]}\end{array}$ & $\begin{array}{l}\text { Granulosa } \\
\text { cells }\end{array}$ & 16 PCOS vs 8 controls & $\begin{array}{l}29.69 \pm 2.39 / \\
31.75 \pm 4.40\end{array}$ & $\begin{array}{l}24.07 \pm 5.33 / \\
21.17 \pm 3.06\end{array}$ & Upregulated: miR-93, 107 \\
\hline $\begin{array}{l}\text { Shi et al. } \\
2015 \text { [53] }\end{array}$ & Cumulus cells & 24 PCOS vs 24 controls & $\begin{array}{l}28.3 \pm 3.3 / 28.5 \pm \\
3.6\end{array}$ & $\begin{array}{l}21.5 \pm 2.5 / 20.7 \pm \\
2.1\end{array}$ & $\begin{array}{l}\text { Downregulated: } \\
\text { miR-483-5p and } 486-5 p\end{array}$ \\
\hline $\begin{array}{l}\text { Liu et al. } \\
2015 \text { [54] }\end{array}$ & Cumulus cells & 10 PCOS vs 10 controls & $\begin{array}{l}27.4 \pm 2.6 / 29.4 \pm \\
3.0\end{array}$ & $\begin{array}{l}22.0 \pm 3.5 / \\
23.5 \pm 3.2\end{array}$ & $\begin{array}{l}\text { Upregulated: } \\
\text { miR-513a-3p, 508-3p, 513b, 514, 509-5p, 513c, 144, } \\
\text { 510, 509-3p and 508-5p } \\
\text { Downregulated: miR-151-3p, 720, 615-3p, 127-3p, } \\
\text { 455-3p, 342-3p and 654-3p }\end{array}$ \\
\hline $\begin{array}{l}\text { Xu et al. } \\
2015 \text { [55] }\end{array}$ & $\begin{array}{l}\text { Cumulus } \\
\text { granulosa cells }\end{array}$ & 21 PCOS vs 20 controls & $\begin{array}{l}28.76 \pm 3.51 / \\
29.43 \pm 3.92\end{array}$ & $\begin{array}{l}24.01 \pm 3.39 / \\
21.68 \pm 2.99\end{array}$ & $\begin{array}{l}\text { Upregulated: } \\
\text { miR-423-3p, 3651, 3653, 151b, 1273 g-3p, 590-5p, } \\
\text { 3648, 7845-5p, 27a-5p, 1275, 483-3p, 7-5p, 483-5p, } \\
\text { 10a-5p, 184, 619-5p, 513b-5p, 1307-5p, 4516, 1307- } \\
\text { 3p, 514b-5p } \\
\text { Downregulated: } \\
\text { miR-3529-3p, 7974, 3065-5p, 214-3p, 200a-3p, 203a, } \\
\text { 4732-5p, 423-5p, 3184-5p, 548n, 221-3p, 149-5p, } \\
\text { 1298-5p, 193a-3p, 365a-3p, 219a-1-3p, 550b-2-5p, } \\
\text { 144-5p, 660-5p, 548e-3p, 652-3p, 222-3p,506-5p, } \\
\text { 193a-5p, 210-5p, 365b-5p, 330-3p, 223-3p, 186-5p, } \\
\text { 185-5p, 92b-3p, 199b-3p, 766-5p, 15b-3p, 339-5p, } \\
\text { 3960, 766-3p, let-7a-3p }\end{array}$ \\
\hline Study & $\begin{array}{l}\text { Detected in } \\
\text { tissue/cell }\end{array}$ & No. of PCOS and control & $\begin{array}{l}\text { Age of PCOS/ } \\
\text { control (years) }\end{array}$ & $\begin{array}{l}\text { BMl of PCOS/ } \\
\text { control (m/kg2) }\end{array}$ & Dysregulated miRNAs \\
\hline $\begin{array}{l}\text { Huang et al. } \\
2016[56]\end{array}$ & Cumulus cells & 18 PCOS vs 18 controls & $\begin{array}{l}32.6 \pm 3.1 / 34.6 \pm \\
2.2\end{array}$ & $\begin{array}{l}21.6 \pm 1.5 / \\
21.4 \pm 1.8\end{array}$ & $\begin{array}{l}\text { Upregulated: } \\
\text { miR-135b-5p, 152, 193a-3p, 194-5p, 196a-5p, 200b- } \\
\text { 3p, 423-3p, 454-3p, 455-5p, 4659a-3p, 509-3-5p, } \\
\text { 509-3p, 513b-5p, 652-5p, 95, 1273e }\end{array}$ \\
\hline $\begin{array}{l}\text { Cai et al. } \\
2017[57]\end{array}$ & $\begin{array}{l}\text { Granulosa } \\
\text { cells }\end{array}$ & 25 PCOS vs 25 controls & $29 \pm 3.5 / 29 \pm 3.5$ & NA/ NA & Downregulated: miR-145 \\
\hline $\begin{array}{l}\text { Zhang et al. } \\
2017 \text { [58] }\end{array}$ & Cumulus cells & 21 PCOS vs 12 controls & $\begin{array}{l}28.7 \pm 2.6 / 29.4 \pm \\
3.1\end{array}$ & $\begin{array}{l}21.4 \pm 3.3 / 22.7 \pm \\
2.9\end{array}$ & $\begin{array}{l}\text { Downregulated: } \\
\text { miR-320a }\end{array}$ \\
\hline $\begin{array}{l}\text { He et al. } \\
2018[59]\end{array}$ & $\begin{array}{l}\text { Granulosa } \\
\text { cells }\end{array}$ & 62 PCOS vs 61 controls & $\begin{array}{l}28.27 \pm 3.10 / \\
28.71 \pm 2.46\end{array}$ & $\begin{array}{l}24.40 \pm 3.34 / \\
21.77 \pm 2.37\end{array}$ & $\begin{array}{l}\text { Downregulated: } \\
\text { miR-141 and 200c }\end{array}$ \\
\hline $\begin{array}{l}\text { Mao et al. } \\
2018 \text { [60] }\end{array}$ & $\begin{array}{l}\text { Granulosa } \\
\text { cells }\end{array}$ & 43 PCOS vs 26 controls & $\begin{array}{l}30.2 \pm 2.8 / 31.1 \pm \\
2.1\end{array}$ & $\begin{array}{l}23.2 \pm 1.7 / 22.1 \pm \\
1.6\end{array}$ & $\begin{array}{l}\text { Downregulated: } \\
\text { miR-126-5p and } 29 a-5 p\end{array}$ \\
\hline
\end{tabular}


Table 1 Studies evaluating altered miRNA expression in women with and without PCOS (Continued)

\begin{tabular}{|c|c|c|c|c|c|}
\hline Study & $\begin{array}{l}\text { Detected in } \\
\text { tissue/cell }\end{array}$ & No. of PCOS and control & $\begin{array}{l}\text { Age of PCOS/ } \\
\text { control (years) }\end{array}$ & $\begin{array}{l}\text { BMI of PCOS/ } \\
\text { control }(\mathrm{m} / \mathrm{kg} 2)\end{array}$ & Dysregulated miRNAs \\
\hline $\begin{array}{l}\text { Wang et al. } \\
2018 \text { [61] }\end{array}$ & $\begin{array}{l}\text { Granulosa } \\
\text { cells }\end{array}$ & 21 PCOS vs 13 controls & $\begin{array}{l}28.67 \pm 3.70 / \\
30.00 \pm 2.77\end{array}$ & $\begin{array}{l}24.69 \pm 1.19 / \\
23.63 \pm 1.70\end{array}$ & Upregulated: miR-27a-3p \\
\hline $\begin{array}{l}\text { Zhong et al. } \\
2018 \text { [62] }\end{array}$ & $\begin{array}{l}\text { Granulosa } \\
\text { cells, ovarian } \\
\text { cortex }\end{array}$ & 18 PCOS vs 10 controls & NA/ NA & NA/ NA & Downregulated: miR-19b \\
\hline $\begin{array}{l}\text { Geng et al. } \\
2019 \text { [63] }\end{array}$ & $\begin{array}{l}\text { Granulosa } \\
\text { cells }\end{array}$ & 15 PCOS vs 15 controls & $\begin{array}{l}27.23 \pm 1.83 / \\
28.53 \pm 1.85\end{array}$ & $\begin{array}{l}22.17 \pm 2.04 / \\
21.79 \pm 2.13\end{array}$ & Upregulated: miR-99a \\
\hline $\begin{array}{l}\text { Li et al. } 2019 \\
\text { [64] }\end{array}$ & $\begin{array}{l}\text { Granulosa } \\
\text { cells }\end{array}$ & 46 PCOS vs 32 controls & $\begin{array}{l}29.21 \pm 4.78 / \\
29.43 \pm 3.82\end{array}$ & $\begin{array}{l}24.35 \pm 3.32 / \\
23.12 \pm 2.13\end{array}$ & $\begin{array}{l}\text { Upregulated: miR-33b and } 142 \\
\text { Downregulated: miR-423 }\end{array}$ \\
\hline $\begin{array}{l}\text { Luo et al. } \\
2019 \text { [65] }\end{array}$ & $\begin{array}{l}\text { Granulosa } \\
\text { cells }\end{array}$ & 20 PCOS vs 18 controls & $\begin{array}{l}27 \pm 3.26 / 29 \pm \\
3.22\end{array}$ & NA/ NA & Upregulated: miR-23a \\
\hline $\begin{array}{l}\text { Wang et al. } \\
2019[66]\end{array}$ & $\begin{array}{l}\text { Granulosa } \\
\text { cells }\end{array}$ & 24 PCOS vs 21 controls & $\begin{array}{l}28.708 \pm 0.802 / \\
29.571 \pm 0.994\end{array}$ & $\begin{array}{l}25.958 \pm 0.836 / \\
22.173 \pm 0.878\end{array}$ & $\begin{array}{l}\text { Upregulated: } \\
\text { miR-3188 and 3135b }\end{array}$ \\
\hline $\begin{array}{l}\text { Song et al. } \\
2019 \text { [67] }\end{array}$ & $\begin{array}{l}\text { Granulosa } \\
\text { cells }\end{array}$ & 63 PCOS vs 20 controls & $\begin{array}{l}28.21 \pm 2.78 / \\
27.43 \pm 3.62\end{array}$ & $\begin{array}{l}24.35 \pm 2.12 / \\
22.12 \pm 1.73\end{array}$ & $\begin{array}{l}\text { Upregulated: } \\
\text { miR-186 and 135a }\end{array}$ \\
\hline $\begin{array}{l}\text { Hou et al. } \\
2019 \text { [68] }\end{array}$ & $\begin{array}{l}\text { Granulosa } \\
\text { cells }\end{array}$ & 38 PCOS vs 35 controls & $\begin{array}{l}29.60 \pm 0.66 / \\
29.66 \pm 0.82\end{array}$ & $\begin{array}{l}25.25 \pm 0.59 / \\
22.63 \pm 0.53\end{array}$ & $\begin{array}{l}\text { Upregulated: } \\
\text { miR-3188 and 3135b }\end{array}$ \\
\hline $\begin{array}{l}\text { McCallie } \\
\text { et al. } 2010 \\
\text { [69] }\end{array}$ & Blastocysts & 6 PCOS vs 10 controls & NA/ NA & NA/ NA & $\begin{array}{l}\text { Downregulated: } \\
\text { miR- let-7a, 19a, 19b, 24, 92, and } 93\end{array}$ \\
\hline $\begin{array}{l}\text { Chen et al. } \\
2013 \text { [26] }\end{array}$ & Adipose tissue & 11 PCOS vs 11 controls & $\begin{array}{l}27.46 \pm 4.07 / \\
32.41 \pm 6.61\end{array}$ & $\begin{array}{l}28.56 \pm 5.6 / \\
22.89 \pm 2.65\end{array}$ & Upregulated: miR-93, 133 and 223 \\
\hline $\begin{array}{l}\text { Wu et al. } \\
2014[70]\end{array}$ & Adipose tissue & $\begin{array}{l}8 \text { PCOS with IR vs } 8 \text { PCOS } \\
\text { without IR vs } 9 \text { controls } \\
\text { with IR vs } 6 \text { healthy } \\
\text { without IR }\end{array}$ & $\begin{array}{l}27.75 \pm 4.98 / \\
30.00 \pm 5.57 / \\
33.66 \pm 6.37 / \\
32.33 \pm 5.03\end{array}$ & $\begin{array}{l}31.92 \pm 4.95 / \\
25.49 \pm 5.56 / \\
35.78 \pm 7.68 / \\
22.80 \pm 1.32\end{array}$ & $\begin{array}{l}\text { Upregulated in PCOS patients and controls with IR } \\
\text { miR-93, and } 25\end{array}$ \\
\hline $\begin{array}{l}\text { Lin et al. } \\
2015[17]\end{array}$ & $\begin{array}{l}\text { Ovarian theca } \\
\text { interna tissues }\end{array}$ & 10 PCOS vs 8 controls & $\begin{array}{l}28.80 \pm 3.97 / \\
32.00 \pm 2.16\end{array}$ & $\begin{array}{l}24.42 \pm 4.84 / \\
20.51 \pm 2.06\end{array}$ & Downregulated: miR-19b, 92a, 92b, 141, and 200a \\
\hline $\begin{array}{l}\text { Xiang et al. } \\
2016[71]\end{array}$ & Ovary cortex & 20 PCOS vs 20 controls & $\begin{array}{l}27.3 \pm 2.5 / 28.2 \pm \\
3.7\end{array}$ & $\begin{array}{l}26.2 \pm 3.7 / \\
22.0 \pm 2.5\end{array}$ & Downregulated: miR-483 \\
\hline $\begin{array}{l}\text { Yuan et al. } \\
2017 \text { [72] }\end{array}$ & Ovarian tissue & 20 PCOS vs 20 controls & $N A / N A$ & NA/NA & Downregulated: miR-320 \\
\hline $\begin{array}{l}\text { McAllister } \\
\text { et al. } 2019 \\
\text { [73] }\end{array}$ & $\begin{array}{l}\text { Ovarian theca } \\
\text { cells }\end{array}$ & 7 PCOS vs 7 controls & NA/ NA & NA/NA & $\begin{array}{l}\text { Upregulated: } \\
\text { miR-100-5p, 99b-5p, 1271-5p, 409-5p, 744, 410-3p, } \\
\text { 127-3p, 654-5p, 494-3p, 1301-3p, 502-3p, 501-3p } \\
\text { and } 1293 \\
\text { Downregulated: } \\
\text { miR-125a-3p,148b-5p, 195-5p,130b-3p and 4542a- } \\
5 p\end{array}$ \\
\hline
\end{tabular}

Abbreviations: PCOS polycystic ovary syndrome, $B M I$ body mass index, NA not available, IR insulin resistance

theca cells [73], ovarian theca interna tissues [17], ovary cortex [62, 71] and ovarian tissue [72]. McCallie et al. [69] reported that blastocysts isolated from patients with PCOS exhibited significantly decreased expression of six miRNAs (miR-let-7a, miR-19a, miR-19b, miR-24, miR92, and miR-93) in comparison with donor fertile control blastocysts. Two studies suggested that the expression of miR-93 was significantly increased in adipose tissue from IR/non-PCOS and all PCOS patients compared with controls [26, 70]. Furthermore, expression of miR-483 was significantly decreased in ovary cortex lesion from PCOS patients. It is conjectured that miR-483 inhibited cell proliferation possibly by targeting IGF1, and may be an alternative biomarker for PCOS diagnosis and treatment.

\section{Meta-analysis for miRNAs expression}

Due to the limited consistency between these studies, if mean expression level and FC of same miRNA was reported in more than three articles, this miRNA was selected to perform our meta-analysis. Finally, only miR320 and miR-93 were included. Our meta-analysis included a total of 9 individual studies, of which 5 studies reported on miR-320 and 4 studies reported on miR-93. Real time polymerase chain reaction (RT-PCR) was used to measure the expression of miRNAs in all studies. 
Among these studies, two detected miRNA expression in two different tissues [16, 46]. Three studies examined the expression of miRNAs in FF, three in GCs, one in Cumulus cells, one in serum, one in plasma, one in adipose tissue, and one in ovarian tissue.

Forest plot of miR-320 expression in PCOS patients and controls is shown in Fig. 2. The metaanalysis revealed that the expression of miR-320 was downregulated in PCOS patients compared to healthy controls (WMD $-0.49,95 \% \mathrm{CI}-0.79$ to $0.20, \quad P<0.001)$; however, significant heterogeneity was existed among included studies $\left(\mathrm{I}^{2}=87 \%\right)$. To identify the potential sources of heterogeneity, subgroup analysis was performed based on type of sample source. For the expression of miR-320, there was no significant difference among studies detected in FF (two trials, WMD 1.16, 95\%CI -2.77 to 5.08), studies detected in GCs (two trials, WMD 1.06, $95 \% \mathrm{CI}-2.78$ to 4.98$)$ and studies detected in other tissues by the test of interaction $(P=0.37$, Supplemental Figure 1). The reasons for this heterogeneity have not been identified.

Forest plot of miR-93 expression in PCOS compared to the controls is shown in Fig. 3. The expression of miR-93 was upregulated in PCOS patients compared to healthy controls, however, the difference between two groups was not significant (WMD $0.53,95 \% \mathrm{CI}-0.03$ to $1.09, P=0.06$ ), with significant heterogeneity among included studies $\left(\mathrm{I}^{2}=55 \%\right)$.

\section{Sensitivity analysis}

Significant heterogeneity existed among studies for the expression of miR-93 $\left(\mathrm{I}^{2}=55 \%\right)$. The study conducted by Naji et al. [16] showed the miR-93 expression in FF was out of range of other studies and may contribute to the heterogeneity. After excluding this article, the result showed that compared with healthy controls, the expression of miR-93 was upregulated in PCOS patients (WMD $0.75,95 \%$ CI 0.46 to $1.05, P<$ 0.00001 , Fig. 4), without heterogeneity among remaining studies $\left(\mathrm{I}^{2}=0 \%\right)$.

\section{Long non-coding RNAs}

Long non-coding RNAs (lncRNAs) play a crucial part in cell proliferation, differentiation, apoptosis and tumorigenesis via interactions with chromatin modification, RNA-binding proteins, and ceRNA networks [76, 77]. Previous studies have shown that IncRNAs may be involved in follicle development. For example, a study found that lncRNA Neat1 knockout (KO) mice failed to establish successful pregnancy due to low serum progesterone level and corpus luteum dysfunction [78]. To date, ten studies have investigated IncRNAs in women with and without PCOS [79-88] (Table 2).

Three studies have examined lncRNAs in peripheral blood leukocytes of women with PCOS [79, 80, 88]. Liu et al. [79] evaluated C-Terminal binding protein 1 antisense (CTBP1-AS) in peripheral blood leukocytes in women with PCOS $(n=23)$ and healthy controls $(n=$ 17). Researchers found that expression of CTBP1-AS was significantly higher in women with PCOS. Further study by Liu et al. observed that expression of IncRNA SRA was overtly elevated in PCOS patients compared with healthy women [80]. Another study by Li et al. showed expression levels of lncRNA H19 in peripheral blood leukocytes from PCOS women were significantly higher than in healthy controls. Women with higher expression levels of IncRNA H19 have a significantly higher risk of PCOS than individuals with lower expression level. Those findings indicated that elevated IncRNA H19 levels may be a useful biomarker for early stage of PCOS for susceptible individuals. However, limitations of these three studies should not be ignored, such as the relatively small sample size, and the study sample selection of peripheral blood leukocytes. As we all know, PCOS is a systemic endocrine disease, which cannot be reflected merely by peripheral blood leukocytes.

Four studies have examined lncRNAs in GCs / cumulus cells of women with PCOS [81-83, 87]. Two studies used a microarray to compare lncRNA profiles in cumulus cells / GCs between women with and without PCOS. Huang et al. [83] showed that 620 lncRNAs expressions were upregulated and only three lncRNAs expressions

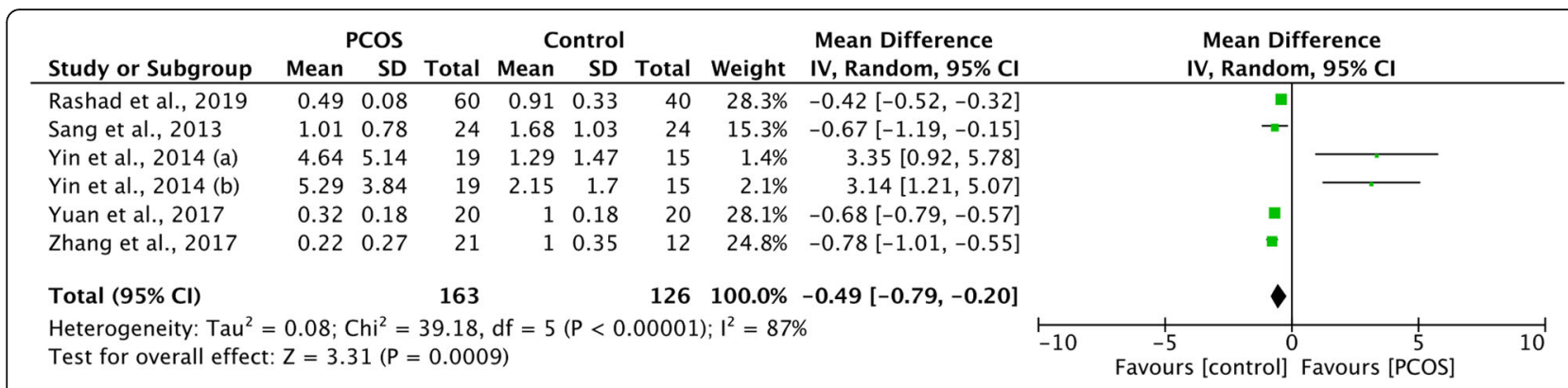

Fig. 2 Forest plot of miR-320 expression in PCOS patients and controls. Abbreviations: PCOS, polycystic ovary syndrome 


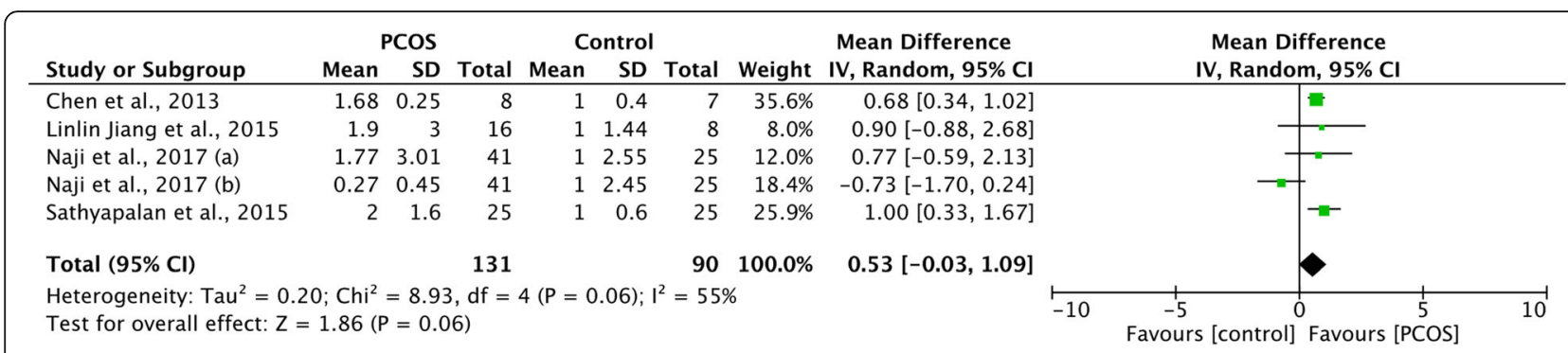

Fig. 3 Forest plot of miR-93 expression in PCOS patients and controls. Abbreviations: PCOS, polycystic ovary syndrome

were down-regulated in PCOS cumulus cells, while Liu et al. [82] found that 692 lncRNAs expressions were upregulated and 170 lncRNAs expressions were downregulated in PCOS GCs. These data all indicate that upregulated expression of IncRNAs in PCOS was more common than that of down-regulation.

On the whole, these studies have identified a number of lncRNAs that proved to aggravate development of PCOS. However, discrepancy between the results of different studies implies that existing evidence is not enough to draw firm conclusions so far.

\section{Circular RNAs}

Circular RNAs (circRNAs) are generated from precursor mRNA (pre-mRNA) via head-to-tail backsplicing and function as miRNA sponges. Many studies have demonstrated that circRNAs are differentially expressed in a variety of diseases, especially in tumors [89-92]. In recent years, expression profiles of circular RNA in preimplantation embryos and human GCs during maternal aging have been extensively studied. Some studies found that circular RNAs are closely related to the development of oocyte and embryos [93, 94].

Up to now, four studies have investigated discrepancy of circRNAs between PCOS patients and healthy controls [95-98] (Table 3). Two of them used microarray analysis to compare circRNA expression profiles in cumulus cells from women with and without PCOS in order to uncover potential biological functions [95, 96]. Che et al. have shown that a total of 1032 circRNAs' expression was significantly changed in PCOS patients, including 311 circRNAs that were up-regulated and 721
circRNAs down-regulated [95]. Four aberrantly expressed circRNAs (hsa_circ_0083952, hsa_circ 0082709, hsa_circ_0002425, and hsa_circ_0015168) showed statistical significance after Bonferroni correction. Another study by $\mathrm{Ma}$ et al. revealed that a total of 286 circRNAs (167 upregulated and 119 downregulated) were significantly altered in cumulus cells of PCOS patients [96]. Further analysis showed that expression levels of hsa_circ_0043533 and hsa_circ_0043532 were significantly higher in PCOS group after quantitative real-time polymerase chain reaction (qRT-PCR) validation, while expression level of hsa_circ_0097636 was significantly lower versus the non-PCOS group. They further found that circRNAs with abnormal expression level contained miRNA-binding sites. Some miRNAs were associated with PCOS indicating that circRNAs may be implicated in PCOS by interactions with PCOSrelated miRNAs. However, the size of samples in these two studies was limited. A larger population is required for further investigation.

A recent study [98] explored circRNAs expression profiles in GCs from PCOS women of reproductive age. They found that 4 circRNAs expressions were upregulated in PCOS group compared with healthy controls, whereas 23 circRNAs expressions were downregulated. Gene ontology analysis showed that dysregulated circRNAs were mainly involved in inflammation, proliferation, and the vascular endothelial growth factor (VEGF) signaling pathway. Moreover, a study investigated circRNAs expression in exosomes of FF obtained from women with and without PCOS [97]. They identified that 167 circRNAs expressions were upregulated and

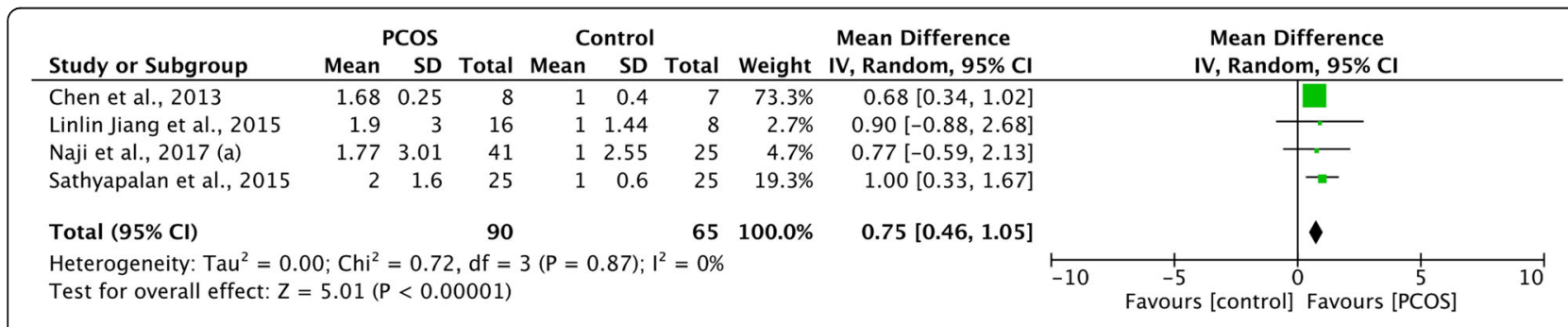

Fig. 4 Sensitivity analysis of miR-93 expression in PCOS patients and controls. Abbreviations: PCOS, polycystic ovary syndrome 
Table 2 Studies evaluating altered IncRNA expression in women with and without PCOS

\begin{tabular}{|c|c|c|c|c|c|}
\hline Study & $\begin{array}{l}\text { Detected in } \\
\text { tissue/cell }\end{array}$ & No. of PCOS and control & $\begin{array}{l}\text { Age of PCOS/ } \\
\text { control (years) }\end{array}$ & $\begin{array}{l}\text { BMI of PCOS/ } \\
\text { control }(\mathrm{m} / \mathrm{kg} 2)\end{array}$ & Dysregulated IncRNAs \\
\hline $\begin{array}{l}\text { Liu et al. } \\
2015 \text { [79] }\end{array}$ & $\begin{array}{l}\text { Peripheral blood } \\
\text { leukocytes }\end{array}$ & 23 PCOS vs 17 controls & $\begin{array}{l}28.44 \pm 0.37 / \\
29.71 \pm 0.44\end{array}$ & $\begin{array}{l}28.88 \pm 0.37 / 27.01 \pm \\
1.1\end{array}$ & Upregulated: IncRNA CTBP1-AS \\
\hline $\begin{array}{l}\text { Liu et al. } \\
2015 \text { [80] }\end{array}$ & $\begin{array}{l}\text { Peripheral blood } \\
\text { leukocytes }\end{array}$ & 23 PCOS vs 17 controls & $\begin{array}{l}28.44 \pm 0.37 / \\
29.71 \pm 0.44\end{array}$ & $\begin{array}{l}27.74 \pm 1.56 / \\
26.61 \pm 1.10\end{array}$ & Upregulated: IncRNA SRA \\
\hline $\begin{array}{l}\text { Huang et al. } \\
2016[81]\end{array}$ & Cumulus cells & 35 PCOS vs 35 controls & $\begin{array}{l}32.6 \pm 3.1 / 34.6 \pm \\
2.2\end{array}$ & $\begin{array}{l}21.6 \pm 1.5 / 21.4 \pm \\
1.8\end{array}$ & $\begin{array}{l}620 \text { upregulated and } 3 \\
\text { downregulated } \\
\text { The most upregulated: } \\
\text { IncRNA ENST00000433673, } \\
\text { The most downregulated: } \\
\text { IncRNA NR_027436 }\end{array}$ \\
\hline $\begin{array}{l}\text { Liu et al. } \\
2017 \text { [82] }\end{array}$ & Granulosa cells & 7 PCOS vs 7 controls & $\begin{array}{l}29.71 \pm 3.59 / \\
30.14 \pm 2.97\end{array}$ & $\begin{array}{l}20.8 \pm 1.96 / \\
22.34 \pm 1.12\end{array}$ & $\begin{array}{l}692 \text { upregulated and } 170 \\
\text { downregulated } \\
\text { The most upregulated: } \\
\text { IncRNA ENST00000533082, } \\
\text { The most downregulated: } \\
\text { IncRNA ENST00000448179 }\end{array}$ \\
\hline $\begin{array}{l}\text { Huang et al. } \\
2018 \text { [83] }\end{array}$ & Cumulus cells & 30 PCOS vs 30 controls & $\begin{array}{l}32.6 \pm 3.1 / 33.6 \pm \\
2.2\end{array}$ & $\begin{array}{l}21.6 \pm 1.5 / 21.4 \pm \\
1.6\end{array}$ & Upregulated: IncRNA PWRN2 \\
\hline $\begin{array}{l}\text { Jiao et al. } \\
2018 \text { [84] }\end{array}$ & Follicular fluid & 10 PCOS vs 8 controls & $\begin{array}{l}30.6 \pm 3.86 / 30.0 \pm \\
4.21\end{array}$ & $\begin{array}{l}25.9 \pm 3.14 / 24.7 \pm \\
3.69\end{array}$ & $\begin{array}{l}\text { A total of } 1583 \text { novel IncRNAs } \\
\text { were identified }\end{array}$ \\
\hline $\begin{array}{l}\text { Lin et al. } \\
2018[85]\end{array}$ & Serum & $\begin{array}{l}16 \text { PCOS without IR vs } 30 \text { PCOS with } \\
\text { IR vs } 30 \text { healthy controls }\end{array}$ & $\begin{array}{l}28.3 \pm 3.1 / 31.3 \pm \\
4.6 / 26.8 \pm 6.7\end{array}$ & $\begin{array}{l}20.9 \pm 3.6 / 25.1 \pm \\
3.5 / 19.5 \pm 2.4\end{array}$ & $\begin{array}{l}\text { Downregulated in PCOS patients } \\
\text { with IR: IncRNA GAS5 }\end{array}$ \\
\hline $\begin{array}{l}\text { Zhao et al. } \\
2018 \text { [86] }\end{array}$ & $\begin{array}{l}\text { Luteinized } \\
\text { granulosa cells }\end{array}$ & 30 PCOS vs 30 controls & $28 \pm 3 / 29 \pm 3$ & $\begin{array}{l}23.3 \pm 2.9 / 21.8 \pm \\
2.4\end{array}$ & $\begin{array}{l}\text { Upregulated: } \\
\text { LINC-01572:28 }\end{array}$ \\
\hline $\begin{array}{l}\text { Yang et al. } \\
2019 \text { [87] }\end{array}$ & Granulosa cells & 44 PCOS vs 34 controls & $\begin{array}{l}31.2 \pm 3.4 / 30.9 \pm \\
3.1\end{array}$ & NA/NA & Upregulated: IncRNA BANCR \\
\hline $\begin{array}{l}\text { Li et al. } 2019 \\
\text { [88] }\end{array}$ & $\begin{array}{l}\text { Peripheral blood } \\
\text { leukocytes }\end{array}$ & 20 PCOS vs 20 controls & $\begin{array}{l}28.45 \pm 1.35 / \\
31.7 \pm 1.52\end{array}$ & $\begin{array}{l}25.21 \pm 0.86 / \\
20.56 \pm 0.58\end{array}$ & Upregulated: IncRNA H19 \\
\hline
\end{tabular}

Abbreviations: PCOS polycystic ovary syndrome, BMI body mass index, NA not available, IR insulin resistance

245 circRNAs expressions were downregulated, a circRNA-microRNA interaction network was constructed based on research data. Differentially expressed circRNAs in PCOS were linked with pathways including inflammation, bacterial infection and oxidative stress.

\section{Short interfering RNAs}

Short interfering RNAs (siRNAs), 21-25 long nucleotides, double stranded (ds) RNAs act in gene silencing through binding to the sequence of their target mRNAs $[99,100]$. Three studies have demonstrated the application of siRNA-mediated gene silencing in PCOS research

Table 3 Studies evaluating altered circRNA expression in women with and without PCOS

\begin{tabular}{|c|c|c|c|c|c|}
\hline Study & $\begin{array}{l}\text { Detected in } \\
\text { tissue/cell }\end{array}$ & $\begin{array}{l}\text { No. of PCOS } \\
\text { and control }\end{array}$ & $\begin{array}{l}\text { Age of PCOS/ } \\
\text { control (years) }\end{array}$ & $\begin{array}{l}\text { BMI of PCOS/ } \\
\text { control }(\mathrm{m} / \mathrm{kg} 2)\end{array}$ & Dysregulated circRNAs \\
\hline $\begin{array}{l}\text { Che et al. } \\
2019 \text { [95] }\end{array}$ & Cumulus cells & $\begin{array}{l}20 \text { PCOS vs } 20 \\
\text { controls }\end{array}$ & $\begin{array}{l}30.4 \pm 2.5 / 29.8 \pm \\
3.1\end{array}$ & $\begin{array}{l}22.3 \pm 1.4 / 21.8 \pm \\
1.5\end{array}$ & $\begin{array}{l}\text { Downregulated: circRNA-0083952, 0082709, 0002425, and } \\
0015168\end{array}$ \\
\hline $\begin{array}{l}\text { Ma et al. } \\
2019 \text { [96] }\end{array}$ & Cumulus cells & $\begin{array}{l}25 \text { PCOS vs } 25 \\
\text { controls }\end{array}$ & $\begin{array}{l}29.60 \pm 2.76 / \\
31.16 \pm 3.28\end{array}$ & $\begin{array}{l}24.46 \pm 2.47 / \\
21.16 \pm 2.04\end{array}$ & $\begin{array}{l}\text { Upregulated: } \\
\text { circRNA-0043533 and } 0043532 \\
\text { Downregulated: circRNA-0097636 }\end{array}$ \\
\hline $\begin{array}{l}\text { Wang et al. } \\
2019 \text { [97] }\end{array}$ & $\begin{array}{l}\text { Exosomes of } \\
\text { follicle fluids }\end{array}$ & $\begin{array}{l}3 \text { PCOS vs } 3 \\
\text { controls }\end{array}$ & $\begin{array}{l}24,25,27 / 26,27 \\
28\end{array}$ & $\begin{array}{l}22.4,26.4,20.3 / \\
22.9,16,22.3\end{array}$ & $\begin{array}{l}167 \text { upregulated and } 245 \text { downregulated } \\
\text { The top five most upregulated: circRNA-15918_GREB1L,2702_ } \\
\text { ANKH, } 7788 \text { HTT, 5762_SPHKAP, and 8717_FANCL } \\
\text { The top five most downregulated: } \\
\text { circRNA-5172_NBPF20, 14485_MBOAT2, 15481_ATP6V0D1, } \\
6172 \text { LINC-PINT, } \\
\text { and } 6485 \text { _LYRM4 }\end{array}$ \\
\hline $\begin{array}{l}\text { Zhang et al. } \\
2019 \text { [98] }\end{array}$ & $\begin{array}{l}\text { Granulosa } \\
\text { cells }\end{array}$ & $\begin{array}{l}15 \text { PCOS vs } 15 \\
\text { controls }\end{array}$ & $\begin{array}{l}29.20 \pm 2.42 / \\
29.73 \pm 3.39\end{array}$ & $\begin{array}{l}20.82 \pm 1.68 / \\
19.84 \pm 1.00\end{array}$ & $\begin{array}{l}\text { Upregulated: circRNA-0001577 } \\
\text { Downregulated: circRNA-0020093 }\end{array}$ \\
\hline
\end{tabular}


and have revealed potential mechanisms in PCOS [101103] (Table 4).

Follicle stimulating hormone (FSH) stimulates the growth and differentiation of ovarian follicles. Anjali et al. [101] confirmed that FSH specifically increases the expression of IRS- 2 and decreases IRS- 2 mRNA degradation in human GCs. However, in GCs of PCOS women the expression of FSH-stimulated IRS-2 was defective. They further found that after IRS-2 knockdown by siRNA, the defect of FSH may cause the deceleration of follicular growth, which can lead to infertility. These results suggested IRS-2 may contribute to the development of new therapeutic strategies for PCOS patients.

Li et al. [102] demonstrated that increased heat shock protein 90B1 (HSP90B1) levels in PCOS ovarian cells positively correlate with cell survival. Knockdown of HSP90B1 with siRNA increased apoptosis and decreased ovarian cells from patients with PCOS. Thus, the altered expression profile of HSP90B1 has an important effect on the proliferation and survival of ovarian cells, suggesting a key role of HSP90B1 in PCOS pathogenesis.

Song et al. [103] suggested that insulin induced cell apoptosis, stimulated cell proliferation and decreased telomerase activity in GCs from both PCOS women and healthy controls, but insulin receptor gene (INSR) siRNAs transfection blocked the effect of insulin. Thus, insulin induced more GCs apoptosis may be involved in the pathogenesis of PCOS.

\section{Pathophysiological pathways impacted by differentially expressed ncRNAs}

Dysregulated ncRNAs identified in PCOS were involved in various cellular and biological pathways, some of which are implicated in PCOS lesion development (Table 5).

\section{Altered steroidogenesis}

Previous research reported that miR-423-3p directly interacts with AdipoR2 (adiponectin receptor 2) [104]. The expression level of adiponectin receptor 2(AdipoR2) in theca cells of PCOS women was significantly lower than that in normal ovaries. AdipoR2 is a receptor to adiponectin. Destruction of adiponectin and/or adiponectin receptors interfere with normal progesterone production and plays an important part in pathogenesis of hyperandrogenism in PCOS $[105,106]$. Downregulated miR-592 expression in PCOS patients induced a significant increase of luteinizing hormone/ chorionic gonadotropin receptor (LHCGR) mRNA expression, which is also an important factor of hyperandrogenemia in PCOS.

Androgens are important for female reproduction. However, androgens cannot stimulate corresponding targets without androgen receptors, whose abnormality may lead to reproductive defects [107-109]. A study has illustrated that expression of androgen receptors was increased in women with PCOS [110]. Follicular development defects were observed in androgen receptors gene knockout model, suggesting that androgen receptors is also actively involved in sustaining normal ovarian function [111]. A study showed that extra-nuclear androgen receptor signals could enhance expression of antiapoptotic miR-125b. Then, the increased expression of miR-125b may contribute to androgen-induced follicular survival by reducing the number of follicular atresia [112].

In addition, abnormal expression of estrogen receptors may be related to pathogenesis and abnormal follicular development in PCOS as well [113]. Targeted disruption of estrogen receptor-alpha gene in female mice exhibited high level of LH, cystic ovaries and ovulation abnormalities [114]. Moreover, studies have shown that miR-193b and miR-222 could influence estrogen receptor by targeting estrogen receptor 1 (ESR1) gene. MiR-193b has been shown to regulate estrogen signaling [113], while miRNA-222 negatively regulates estrogen receptor-alpha expression at the protein level [115]. Interestingly, miR222 and 193b also have an influence on steroid secretion. Besides, Long et al. found miR-146a was negatively correlated with serum testosterone levels in PCOS women [24]. The study by Huang et al. [56] indicated that miR-509-3p improved the secretion of oestradiol by inhibiting expression of MAP $3 \mathrm{~K} 8$. These results will help to illuminate regulation of steroid secretion in the pathogenesis of PCOS.

LncRNAs, which regulate response of androgen, estrogen and progesterone receptors have been identified,

Table 4 The utility of siRNA mediated gene silencing approaches in PCOS research

\begin{tabular}{llllll}
\hline Study & $\begin{array}{l}\text { Detected in } \\
\text { tissue/cell }\end{array}$ & $\begin{array}{l}\text { No. of PCOS and } \\
\text { control }\end{array}$ & $\begin{array}{l}\text { Age of PCOS/ } \\
\text { control (years) }\end{array}$ & $\begin{array}{l}\text { BMI of PCOS/ } \\
\text { control (m/kg2) }\end{array}$ & siRNA Transfection \\
\hline $\begin{array}{l}\text { Anjali et al. } \\
\text { 2015 [101] }\end{array}$ & Granulosa cells & $\begin{array}{l}18 \text { PCOS vs } 30 \\
\text { controls }\end{array}$ & NA/ NA & NA/ NA & SiRNAs target IRS-2, PI3K, Akt \\
$\begin{array}{l}\text { Li et al. 2016 } \\
\text { [102] }\end{array}$ & Granulosa cells & $\begin{array}{l}10 \text { PCOS vs } 10 \\
\text { controls }\end{array}$ & NA/ NA & NA/ NA & SiRNAs target heat shock protein 90B1 \\
$\begin{array}{l}\text { Song et al. } \\
\text { 2018 [103] }\end{array}$ & Granulosa cells & $\begin{array}{l}25 \text { PCOS vs 25 } \\
\text { controls }\end{array}$ & $\begin{array}{l}27.77 \pm 4.34 / 29.39 \pm \\
3.37\end{array}$ & $\begin{array}{l}21.24 \pm 3.59 / 22.02 \pm \\
3.30\end{array}$ & $\begin{array}{l}\text { SiRNA 439, 1930, and 2117 target human } \\
\text { insulin receptor gene }\end{array}$ \\
\hline
\end{tabular}

Abbreviations: $P C O S$ polycystic ovary syndrome, BMI body mass index, NA not available 
Table $\mathbf{5}$ List of ncRNAs observed in PCOS

\begin{tabular}{|c|c|c|c|c|c|}
\hline ncRNAs & $\begin{array}{l}\text { Detected in } \\
\text { cell/tissue }\end{array}$ & Expression & $\begin{array}{l}\text { Target gene(s)/acting } \\
\text { pathway }\end{array}$ & Reported function(s) & References \\
\hline \multirow[t]{4}{*}{ miR-93 } & Adipose tissue & $\uparrow$ & GLUT4 & Correlated with insulin resistance & [26] \\
\hline & Granulose cells & $\uparrow$ & CDKN1A & Promotes proliferation and cell cycle progression & [27] \\
\hline & Granulose cells & $\uparrow$ & SMAD7 and TGFBR2 & Impaired follicle development & [49] \\
\hline & Plasma & $\uparrow$ & $\begin{array}{l}\text { NGF Signalling and HGF } \\
\text { Signalling }\end{array}$ & Correlated with insulin resistance & {$[32]$} \\
\hline \multirow[t]{5}{*}{ miR-320 } & Serum & $\downarrow$ & $\begin{array}{l}\text { Through ET-1 regulating } \\
\text { ERK1/2 signalling pathway }\end{array}$ & Promotes cell mitosis & [44] \\
\hline & Cumulus cells & $\downarrow$ & RUNX2 & Estrogen deficiency & [58] \\
\hline & Ovarian tissue & $\downarrow$ & $\begin{array}{l}\text { Through IRS-1 regulating } \\
\text { ERK1/2 signalling pathway }\end{array}$ & Inhibits insulin resistance & [72] \\
\hline & Follicular fluid & $\downarrow$ & RAB5B & Correlated with insulin resistance & [25] \\
\hline & $\begin{array}{l}\text { Follicular fluid, } \\
\text { granulosa cells }\end{array}$ & $\uparrow$ & E2F1 and SF-1 & $\begin{array}{l}\text { Inhibited estradiol release and cell proliferation; enhanced } \\
\text { progesterone synthesis }\end{array}$ & {$[46]$} \\
\hline miR-9 & Follicular fluid & $\uparrow$ & IRS2, SYT1, IL8 & Mediates the effects of insulin; steroid synthesis & [45] \\
\hline miR-18b & Follicular fluid & $\uparrow$ & IRS2, SYT1, IL8 & Mediates the effects of insulin; steroid synthesis & [45] \\
\hline \multirow[t]{2}{*}{ miR-135a } & Follicular fluid & $\uparrow$ & IRS2, SYT1, IL8 & Mediates the effects of insulin; steroid synthesis & {$[45]$} \\
\hline & Granulosa cells & $\uparrow$ & ESR2 & Promoted proliferation and inhibited apoptosis & {$[67]$} \\
\hline miR-186 & Granulosa cells & $\uparrow$ & ESR2 & Promoted proliferation and inhibited apoptosis & [67] \\
\hline \multirow[t]{2}{*}{$\operatorname{miR}-21$} & Serum & $\uparrow$ & LATS1 & Promotes secondary follicle growth & {$[31]$} \\
\hline & Granulose cells & $\uparrow$ & SMAD7 and TGFBR2 & Impaired follicle development & [49] \\
\hline miR-592 & Serum & $\downarrow$ & LHCGR & Inhibited cell viability and cell cycle progression & [33] \\
\hline miR-92a & $\begin{array}{l}\text { Ovarian theca } \\
\text { interna tissues }\end{array}$ & $\downarrow$ & GATA- 6 and IRS-2 & Related to androgenic and insulin signaling pathways & [17] \\
\hline $\operatorname{miR}-223$ & Plasma & $\uparrow$ & $\begin{array}{l}\text { PPAR, IGF-1 and angiopoie- } \\
\text { tin signaling }\end{array}$ & $\begin{array}{l}\text { Correlated with insulin resistance hyperandrogenism, } \\
\text { endometrial response and ovarian follicle development }\end{array}$ & [32] \\
\hline miR-483 & Ovary cortex & $\downarrow$ & IGF1 & Inhibits cell proliferation & [71] \\
\hline \multirow[t]{2}{*}{ miR-483-5p } & $\begin{array}{l}\text { Cumulus } \\
\text { granulosa cells }\end{array}$ & $\downarrow$ & Notch3 and MAPK3 & Related to cell proliferation and apoptosis & [55] \\
\hline & Cumulus cells & $\downarrow$ & IGF2 & Inhibits insulin resistance & [53] \\
\hline miR-486-5p & Cumulus cells & $\downarrow$ & PI3K/Akt & Promote cumulus cell proliferation & [53] \\
\hline miR-509-3p & Cumulus cells & $\uparrow$ & MAP3K8 & Improved oestradiol secretion & {$[56]$} \\
\hline $\begin{array}{l}\operatorname{miR}-6767- \\
5 p\end{array}$ & Serum & $\downarrow$ & & Negatively associated with fasting glucose & {$[36]$} \\
\hline miR-145 & Granulosa cells & $\downarrow$ & IRS1 & Negatively Regulates Cell Proliferation & {$[57]$} \\
\hline miR-126-5p & Granulosa cells & $\downarrow$ & Klotho-associated signaling & Involved in apoptosis of cells & {$[60]$} \\
\hline miR-29a-5p & Granulosa cells & $\downarrow$ & Klotho-associated signaling & Involved in apoptosis of cells & {$[60]$} \\
\hline miR-27a-3p & Granulosa cells & $\uparrow$ & SMAD5 & Decreased cell proliferation and promoted cell apoptosis & [61] \\
\hline miR-335-5p & Follicular fluid & $\downarrow$ & SGK3 & Involved in granulosa cells proliferation & [51] \\
\hline miR-873-5p & Follicular fluid & $\uparrow$ & Heme oxygenase-1 (HO-1) & Involved in apoptosis of cells & {$[52]$} \\
\hline miR-19b & Granulosa cells & $\downarrow$ & IGF-1 & Promotes cell proliferation & {$[62]$} \\
\hline miR-99a & Granulosa cells & $\uparrow$ & IGF-1 & Regulates proliferation and apoptosis & [63] \\
\hline $\operatorname{miR}-33 b$ & Granulosa cells & $\uparrow$ & TGFBR1 & $\begin{array}{l}\text { Induced dysregulated cell proliferation, apoptosis, and cell } \\
\text { cycle }\end{array}$ & [64] \\
\hline miR-142 & Granulosa cells & $\uparrow$ & TGFBR1 & $\begin{array}{l}\text { Induced dysregulated cell proliferation, apoptosis, and cell } \\
\text { cycle }\end{array}$ & {$[64]$} \\
\hline miR-423 & Granulosa cells & $\downarrow$ & SMAD7 & $\begin{array}{l}\text { Induced dysregulated cell proliferation, apoptosis, and cell } \\
\text { cycle }\end{array}$ & {$[64]$} \\
\hline
\end{tabular}


Table 5 List of ncRNAs observed in PCOS (Continued)

\begin{tabular}{|c|c|c|c|c|c|}
\hline ncRNAs & $\begin{array}{l}\text { Detected in } \\
\text { cell/tissue }\end{array}$ & Expression & $\begin{array}{l}\text { Target gene(s)/acting } \\
\text { pathway }\end{array}$ & Reported function(s) & References \\
\hline miR-23a & Granulosa cells & $\uparrow$ & SIRT1 & Promotes cell apoptosis & {$[65]$} \\
\hline $\begin{array}{l}\operatorname{miR}-130 b- \\
3 p\end{array}$ & $\begin{array}{l}\text { Ovarian theca } \\
\text { cells }\end{array}$ & $\uparrow$ & DENND1A Variant 2 & Correlated with androgen biosynthesis & [73] \\
\hline $\begin{array}{l}\text { InCRNA } \\
\text { CTBP1-AS }\end{array}$ & $\begin{array}{l}\text { Peripheral } \\
\text { blood } \\
\text { leukocytes }\end{array}$ & $\uparrow$ & & Reguletes androgen receptor AR activity & [79] \\
\hline InCRNA SRA & $\begin{array}{l}\text { Peripheral } \\
\text { blood } \\
\text { leukocytes }\end{array}$ & $\uparrow$ & & Promote activity of steroid receptors & [80] \\
\hline $\begin{array}{l}\text { IncRNA } \\
\text { PWRN2 }\end{array}$ & Cumulus cells & $\uparrow$ & miR-92b-3p and TMEM120B & Correlated with oocyte nuclear maturation & [83] \\
\hline $\begin{array}{l}\text { IncRNA } \\
\text { GAS5 }\end{array}$ & Serum & $\downarrow$ & & $\begin{array}{l}\text { Correlated with insulin resistance,cell apoptosis and } \\
\text { proliferation }\end{array}$ & [85] \\
\hline $\begin{array}{l}\text { InCRNA } \\
\text { BANCR }\end{array}$ & Granulosa cells & $\uparrow$ & Bax and p53 & promote apoptosis & [87] \\
\hline $\begin{array}{l}\text { IncRNA } \\
\text { LINC-01572: } \\
28\end{array}$ & $\begin{array}{l}\text { Luteinized } \\
\text { granulosa cells }\end{array}$ & $\uparrow$ & SKP2 and p27 & inhibits cell proliferation and cell cycle & [86] \\
\hline IncRNA H19 & $\begin{array}{l}\text { Peripheral } \\
\text { blood } \\
\text { leukocytes }\end{array}$ & $\uparrow$ & & correlated with fasting plasma glucose levels & [88] \\
\hline
\end{tabular}

\begin{abstract}
Abbreviations: TGFBR1 transforming growth factor beta receptor 1, NGF nerve growth factor, HGF hepatic growth factor, ET-1 endothelin-1, IRS1 insulin receptor substrate 1, IRS insulin receptor substrate, SYT1 synaptogamin 1, IL8 interleukin 8, LATS1 large tumor suppressor, LHCGR luteinizing hormone/chorionic gonadotropin receptor, GATA6 GATA-binding factor 6, IRS-2 insulin receptor substrate proteins 2, PPAR peroxisome proliferator receptor, IGF-1 insulin like growth factor-1, SGK3 serum/glucocorticoid-regulated kinase family member $3, \uparrow$ the expression of ncRNAs was upregulated, $\downarrow$ the expression of ncRNAs was downregulated
\end{abstract}

suggesting that lncRNAs act a vital role in the hormoneregulatory networks. For instance, previous studies have shown that, IncRNA SRA has the ability to promote activity of steroid receptors [116-119]. Then, Liu et al. found that the expression level of IncRNA SRA in peripheral blood leukocytes was significantly upregulated in women with PCOS than that in the healthy controls [80]. Thus, there is potential correlation between lncRNA SRA and PCOS. A previous functional study [120] revealed that upregulated CTBP1-AS expression could promote expression of androgen-responsive genes and facilitate androgen receptor mediated transcriptional activity, which is consistent with findings by Liu et al. [79]. Thus, upregulated CTBP1-AS expression might have a potential in the pathogenesis of PCOS hyperandrogenism.

\section{Altered insulin sensitivity and insulin resistance (IR)}

Most women with PCOS have a certain degree of IR and hyperinsulinemia. Up to $70 \%$ of PCOS women have IR, and the prevalence of obesity or overweight in PCOS women is as high as 38 to $88 \%$ [4]. Studies have shown that obese patients with PCOS have a higher level of IR.

Chen et al. found that decreased expression of GLUT4 in adipocytes is closely related to IR regardless of PCOS, and overexpressed miR-93 in adipose tissue reduced GLUT4 expression [26]. This study further observed that the expression of miR-93 was upregulated not only in PCOS, but also in the control group with IR. Thus, miR-93 may play an important part in other IR-related diseases, such as obesity and T2DM. $\mathrm{Wu}$ et al. [70] also demonstrated that increased miR-93 expression in adipose tissue is correlated with PCOS pathology and IR. In another study [121], the expression level of miR-320 was elevated up to 50-fold in $3 \mathrm{~T} 3-\mathrm{L} 1$ adipocytes rendering IR, which was induced by treatment with high insulin and high glucose. Insulin sensitivity was restored in experiments with anti-miR-320 oligo transfection, as was evidenced by the increases of GLUT4 expression, as well as insulin-stimulated glucose uptake. Anti-miR-320 oligo is not only effective in IR adipocytes, but not in normal adipocytes. MiR-320 was found to be highly abundant in FF of women with PCOS, thus it may be a potentially target for improving IR [25].

Compared with PCOS patients without IR and nonPCOS healthy controls, serum lncRNA GAS5 was severely downregulated in PCOS women with IR [85]. The relative expression of IncRNA GAS5 in serum was negatively associated with HOMA-IR. AUC model also identified GAS5 as a good predictive biomarker for PCOS diagnosis. Taken all the data into consideration, it is shown that circulating lncRNA GAS5 may contribute to the development of IR and PCOS. 


\section{Altered ovarian cell proliferation and/or apoptosis}

Evidence from monkey-model-based studies demonstrates that proliferation of GCs was significantly increased while the apoptosis of small antral follicles was significantly decreased with androgen treatment [122]. Furthermore, the imbalance between proliferation and apoptotic rates was also observed in women with PCOS [49]. The study showed that expression level of the proliferation marker, Ki-67, was significantly higher in the PCOS granulosa cells.

Study by Chen et al. shown that upregulated expression of miR-513b-5p promoted apoptosis and inhibited cell proliferation in gastric cancer by targeting high mobility group-box 3 protein (HMGB3) [123]. Thus, hypothesis was raised that miR-513b-5p in the cumulus cells of PCOS patients might be implicated in regulation of apoptosis, which further affected atretic process of the follicles and led to follicular maturation disorder. In women with PCOS, a study has shown that miR-320 functions as a regulator of cell proliferation and hormone synthesis through directly inhibiting the expression of E2F1 and SF-1 [46]. Overexpressed miR-93 also promotes cell proliferation by targeting CDKN1A in GCs [27]. Interestingly, higher level of miR-93 in circulation [32] and adipose tissue [26] of PCOS patients was uncovered by several studies. It is suggested that miR-93 may have a role in proliferative status of GCs and IR by targeting CDKN1A in GCs and GLUT4 in adipose tissue, respectively [27]. Decreased level of miR-145 has been demonstrated to be involved in negative regulation of GCs proliferation in PCOS by targeting insulin receptor substrate 1 (IRS1) inhibits [57].

Several lncRNAs have also been confirmed to be involved in the regulation of cell proliferation and apoptosis. A large number of studies have shown that GAS5 is implicated in cell apoptosis and proliferation [49, 124]. Decrease regulation of GAS5 in serums might play a role in the pathogenesis of PCOS. In addition, the role of IncRNA BANCR in PCOS is to promote apoptosis by upregulating pro-apoptotic p53 and Bax expression [87]. LncRNA LINC-01572:28 inhibited GC growth by decreasing $\mathrm{p} 27$ protein degradation in patients with PCOS [86].

\section{Discussion}

This is the first systematic review and meta-analysis that summarized and evaluated all relevant published literature focusing on miRNAs, lncRNAs, circRNAs, and siRNAs in PCOS from human research. PCOS is a syndrome with many clinical manifestations, which has a major impact on the quality of life, especially for premenopausal women. However, it is difficult to explicitly expound the pathophysiology of PCOS, since it involves endocrinology, gynaecology, diabetology, and other areas. At present, the mechanisms underlying development of anovulation, IR and dyslipidemia in PCOS patients have not been fully clarified. Understanding molecular regulations that cause differential expression of ncRNAs is helpful to elucidate the pathogenesis of PCOS.

Our meta-analysis suggested that compared with healthy controls, the expression of miR-93 was upregulated in PCOS patients. Besides, the expression of miR320 was downregulated in PCOS patients, with significant heterogeneity. The present systematic review suggested that a large number of ncRNAs were reported to exhibit altered levels in plasma, serum, FF, or GCs from PCOS patients compared with healthy controls. However, the miRNA profile varies between studies. This could be attributed to studied populations, the heterogenic nature of PCOS, differences in the control groups, or different methods. Thus, larger well-powered studies are needed to identify candidate miRNAs that are most relevant to PCOS. The aberrant ncRNAs expression might lead to abnormal steroidogenesis, adipocyte dysfunction, altered ovarian cell proliferation, and/or apoptosis. These ncRNA-related symptoms mentioned above help to explain the pathophysiology of PCOS. However, specific role of ncRNAs in the development of PCOS remains unclear because one ncRNA-centered pathway may have multiple mRNA targets and one mRNA 3'UTR may also be regulated by numerous ncRNAs. It is unattainable so far to distinguish whether the altered ncRNAs expression profile is the cause or the result of PCOS. However, it appears that ncRNAs could serve as effective biomarkers for PCOS diagnosis and prognosis.

The strength of this systematic review and metaanalysis is an extensive literature search. We searched main databases, including PubMed, Medline, Web of Science, and Embase. Our review outlines biological function of these PCOS-related ncRNAs from human research, which has proved that dysregulation of ncRNAs is an important factor in the pathophysiology of PCOS. There are several limitations in our study. Firstly, most of studies included in this review had a relatively small sample size, and the results were inconsistent or even contradictory. Secondly, many trials did not provide FC value, thus a limited number of studies were included in our meta-analysis.

Looking ahead, in order to make full use of ncRNAs as non-invasive diagnostic markers, large genome-wide mapping studies are still needed, including a more diverse population of study participants with good clinical characteristics. To ensure consistency of sample collection and processing protocols, it would be ideal to establish a global collaborative database of ncRNAs expression profile under PCOS and non-PCOS conditions. Moreover, due to multifactorial nature of PCOS, 
employing a set of ncRNAs rather than a single ncRNA as biomarkers can improve the accuracy in the diagnosis and assessment of treatment. With the advent of simple and reliable detection software combining bioinformatics analysis, clinical laboratories, and research teams are able to further assess ncRNAs expression profile in various samples. The underlying ncRNAs network in the development of PCOS will continue to be clarified in the near future.

\section{Conclusions}

A large number of ncRNAs with altered levels were observed in plasma, serum, follicular fluid, granulosa cells or other issues from PCOS patients. The aberrant ncRNAs expression in PCOS may lead to aberrant steroidogenesis, adipocyte dysfunction, altered ovarian cell proliferation and/or apoptosis and have the potential to be used as diagnostic biomarkers.

\section{Supplementary Information}

The online version contains supplementary material available at https://doi. org/10.1186/s12958-020-00687-9.

Additional file 1 : Table S1. Quality assessment of the included studies. $\star$, identify high quality choices with a star. All included studies scored 6 or more stars on the modified Newcastle-Ottawa Scale.

Additional file 2 : Figure S1. Subgroup analysis of miR-320 expression in PCOS patients and controls. Abbreviations: PCOS, polycystic ovary syndrome.

\section{Abbreviations}

PCOS: Polycystic ovary syndrome; miRNAs: MicroRNAs; IncRNAs: Long noncoding RNAs; circRNAs: Circular RNAs; siRNAs: Small interfering RNAs; BMI: Body mass index; IR: Insulin resistance; FC: Fold changes;

NOS: Newcastle-Ottawa Scale; WMD: Weighted mean differences

\section{Acknowledgements}

Not applicable.

\section{Authors' contributions}

L.M. conducted literature search, complied data and drafted manuscript. X.S. contributed to literature search and data interpretation. M.T. reviewed manuscript and provided advice. D.Z. contributed to critical discussion, reviewed all drafts of this article, provided extensive advice, and revised the manuscript. The author(s) read and approved the final manuscript.

\section{Funding}

This work was supported by the National Key Research and Development Program of China (2017YFC1001003, 2018YFC1005003), the National Natural Science Foundation of China (No.81771535, 81974224, 82001503), and the Natural Science Foundation of Zhejiang Province (No.LZ18H040001), Zhejiang Provincial Key Medical Thechnology Program (WKJ-ZJ-1826), Zhejiang University Education Foundation Global Partnership Fund, and China Postdoctroal Science Foundation (2020M671760).

\section{Availability of data and materials}

The current study was based on the results of relevant published studies.

\section{Ethics approval and consent to participate}

Not applicable.

\section{Consent for publication}

Not applicable.

\section{Competing interests}

The authors declare that they have no competing interests.

\section{Author details}

${ }^{1}$ Key Laboratory of Reproductive Genetics (Ministry of Education) and Department of Reproductive Endocrinology, Women's Hospital, Zhejiang University School of Medicine, Hangzhou, Zhejiang 310006, People's Republic of China. 'Wenzhou Medical University, Wenzhou, Zhejiang 325000, People's Republic of China.

Received: 9 October 2020 Accepted: 17 December 2020 Published online: 14 January 2021

\section{References}

1. Escobar-Morreale HF. Polycystic ovary syndrome: definition, aetiology, diagnosis and treatment. Nat Rev Endocrinol. 2018;14:270-84.

2. Azziz R, Carmina E, Chen Z, Dunaif A, Laven JS, Legro RS, Lizneva D, Natterson-Horowtiz B, Teede HJ, Yildiz BO. Polycystic ovary syndrome. Nat Rev Dis Primers. 2016;2:16057.

3. Azziz R, Carmina E, Dewailly D, Diamanti-Kandarakis E, Escobar-Morreale HF, Futterweit W, Janssen OE, Legro RS, Norman RJ, Taylor AE, et al. Positions statement: criteria for defining polycystic ovary syndrome as a predominantly hyperandrogenic syndrome: an androgen excess society guideline. J Clin Endocrinol Metab. 2006;91:4237-45.

4. Lindholm A, Andersson L, Eliasson M, Bixo M, Sundstrom-Poromaa I. Prevalence of symptoms associated with polycystic ovary syndrome. Int J Gynaecol Obstet. 2008;102:39-43.

5. Orio F, Muscogiuri G, Nese C, Palomba S, Savastano S, Tafuri D, Colarieti G, La Sala G, Colao A, Yildiz BO. Obesity, type 2 diabetes mellitus and cardiovascular disease risk: an uptodate in the management of polycystic ovary syndrome. Eur J Obstet Gynecol Reprod Biol. 2016;207:214-9.

6. Jin P, Xie Y. Treatment strategies for women with polycystic ovary syndrome. Gynecol Endocrinol. 2018;34:272-7.

7. Piva R, Spandidos DA, Gambari R. From microRNA functions to microRNA therapeutics: novel targets and novel drugs in breast cancer research and treatment (review). Int J Oncol. 2013;43:985-94.

8. Cech TR, Steitz JA. The noncoding RNA revolution-trashing old rules to forge new ones. Cell. 2014;157:77-94.

9. Rinn JL, Chang HY. Genome regulation by long noncoding RNAs. Annu Rev Biochem. 2012;81:145-66.

10. Bartel DP. MicroRNAs: genomics, biogenesis, mechanism, and function. Cell. 2004;116:281-97.

11. Ambros V. microRNAs: tiny regulators with great potential. Cell. 2001;107: 823-6.

12. Suh N, Blelloch R. Small RNAs in early mammalian development: from gametes to gastrulation. Development. 2011;138:1653-61.

13. Qu S, Yang X, Li X, Wang J, Gao Y, Shang R, Sun W, Dou K, Li H. Circular RNA: A new star of noncoding RNAs. Cancer Lett. 2015;365:141-8.

14. Munker R, Calin George A. MicroRNA profiling in cancer: table 1. Clin Sci. 2011;121:141-58.

15. Murri M, Insenser M, Fernandez-Duran E, San-Millan JL, Escobar-Morreale HF. Effects of polycystic ovary syndrome (PCOS), sex hormones, and obesity on circulating miRNA-21, miRNA-27b, miRNA-103, and miRNA-155 expression. J Clin Endocrinol Metab. 2013;98:E1835-44.

16. Naji M, Aleyasin A, Nekoonam S, Arefian E, Mahdian R. Differential expression of miR-93 and miR-21 in granulosa cells and follicular fluid of polycystic ovary syndrome associating with different phenotypes. Sci Rep. 2017;7:14671.

17. Lin L, Du T, Huang J, Huang LL, Yang DZ. Identification of differentially expressed microRNAs in the ovary of polycystic ovary syndrome with hyperandrogenism and insulin resistance. Chin Med J. 2015;128:169-74.

18. Moher D, Liberati A, Tetzlaff J, Altman DG, Group P. Preferred reporting items for systematic reviews and meta-analyses: the PRISMA statement. J Clin Epidemiol. 2009;62:1006-12.

19. Stroup DF. Meta-analysis of observational studies in epidemiology: a proposal for reporting. Jama. 2000;283:2008.

20. Wells G, Shea B, O'Connell D, et al. The Newcastle-Ottawa Scale (NOS) for assessing the quality if nonrandomized studies in meta-analyses. Available at: http://www.ohri.ca/programs/clinical_epidemiology/oxford.asp. Accessed 6 July 2012 
21. Aziz O, Constantinides V, Tekkis PP, Athanasiou T, Purkayastha S, Paraskeva P, Darzi AW, Heriot AG. Laparoscopic versus open surgery for rectal cancer: a meta-analysis. Ann Surg Oncol. 2006;13:413-24.

22. Lee RC, Feinbaum RL, Ambros $V$. The $C$. elegans heterochronic gene lin-4 encodes small RNAs with antisense complementarity to lin-14. Cell. 1993;75:843-54.

23. Hannon GJ, Rivas FV, Murchison EP, Steitz JA. The expanding universe of noncoding RNAs. Cold Spring Harb Symp Quant Biol. 2006;71:551-64.

24. Long W, Zhao C, Ji C, Ding H, Cui Y, Guo X, Shen R, Liu J. Characterization of serum microRNAs profile of PCOS and identification of novel noninvasive biomarkers. Cell Physiol Biochem. 2014;33:1304-15.

25. Sang $Q$, Yao Z, Wang $H$, Feng R, Wang H, Zhao X, Xing Q, Jin L, He L, Wu L, Wang L. Identification of microRNAs in human follicular fluid: characterization of microRNAs that govern steroidogenesis in vitro and are associated with polycystic ovary syndrome in vivo. J Clin Endocrinol Metab. 2013;98:3068-79.

26. Chen YH, Heneidi S, Lee JM, Layman LC, Stepp DW, Gamboa GM, Chen BS, Chazenbalk G, Azziz R. miRNA-93 inhibits GLUT4 and is overexpressed in adipose tissue of polycystic ovary syndrome patients and women with insulin resistance. Diabetes. 2013;62:2278-86.

27. Jiang L, Huang J, Li L, Chen Y, Chen X, Zhao X, Yang D. MicroRNA-93 promotes ovarian granulosa cells proliferation through targeting CDKN1A in polycystic ovarian syndrome. J Clin Endocrinol Metab. 2015;100:E729-38.

28. Imbar T, Eisenberg I. Regulatory role of microRNAs in ovarian function. Fertil Steril. 2014;101:1524-30.

29. Munker R, Calin GA. MicroRNA profiling in cancer. Clin Sci (Lond). 2011;121: $141-58$

30. Ding CF, Chen WQ, Zhu YT, Bo YL, Hu HM, Zheng RH. Circulating microRNAs in patients with polycystic ovary syndrome. Hum Fertil (Camb). 2015:18:22-9.

31. Jiang $L$, Li W, Wu M, Cao S. Ciculating miRNA-21 as a biomarker predicts polycystic ovary syndrome (PCOS) in patients. Clin Lab. 2015;61:1009-15.

32. Sathyapalan T, David R, Gooderham NJ, Atkin SL. Increased expression of circulating miRNA-93 in women with polycystic ovary syndrome may represent a novel, non-invasive biomarker for diagnosis. Sci Rep. 2015;5:16890.

33. Song J, Luo S, Li S-W. miRNA-592 is downregulated and may target LHCGR in polycystic ovary syndrome patients. Reprod Biol. 2015;15:229-37.

34. Zhao C, Liu X, Shi Z, Zhang J, Zhang J, Jia X, Ling X. Role of serum miRNAs in the prediction of ovarian hyperstimulation syndrome in polycystic ovarian syndrome patients. Cell Physiol Biochem. 2015;35:1086-94.

35. Jiang L, Huang J, Chen Y, Yang Y, Li R, Li Y, Chen X, Yang D. Identification of several circulating microRNAs from a genome-wide circulating microRNA expression profile as potential biomarkers for impaired glucose metabolism in polycystic ovarian syndrome. Endocrine. 2016;53:280-90.

36. Song DK, Sung Y-A, Lee $H$. The role of serum microRNA-6767-5p as a biomarker for the diagnosis of polycystic ovary syndrome. PLoS One. 2016; 11:e0163756-6.

37. Eisenberg I, Nahmias N, Novoselsky Persky M, Greenfield C, Goldman-Wohl D, Hurwitz A, Haimov-Kochman R, Yagel S, Imbar T. Elevated circulating micro-ribonucleic acid (miRNA)-200b and miRNA-429 levels in anovulatory women. Fertil Steril. 2017;107:269-75.

38. Hosseini AH, Kohan L, Aledavood A, Rostami S. Association of miR-146a rs2910164 and miR-222 rs2858060 polymorphisms with the risk of polycystic ovary syndrome in Iranian women: A case-control study. Taiwan J Obstet Gynecol. 2017:56:652-6.

39. Xiong W, Lin Y, Xu L, Tamadon A, Zou S, Tian F, Shao R, Li X, Feng Y. Circulatory microRNA 23a and microRNA 23b and polycystic ovary syndrome (PCOS): the effects of body mass index and sex hormones in an Eastern Han Chinese population. J Ovarian Res. 2017;10:10.

40. Ebrahimi SO, Reiisi S, Barjui SP. Increased risk of polycystic ovary syndrome (PCOS) associated with CC genotype of miR-146a gene variation. Gynecol Endocrinol. 2018;34:793-7.

41. Murri M, Insenser M, Fernandez-Duran E, San-Millan JL, Luque-Ramirez M, Escobar-Morreale HF. Non-targeted profiling of circulating microRNAs in women with polycystic ovary syndrome (PCOS): effects of obesity and sex hormones. Metabolism. 2018;86:49-60.

42. Naji M, Nekoonam S, Aleyasin A, Arefian E, Mahdian R, Azizi E, Shabani Nashtaei M, Amidi F. Expression of miR-15a, miR-145, and miR-182 in granulosa-lutein cells, follicular fluid, and serum of women with polycystic ovary syndrome (PCOS). J Ovarian Res. 2018;297:221-31.

43. Nanda D, Chandrasekaran SP, Ramachandran V, Kalaivanan K, Carani Venkatraman A. Evaluation of serum miRNA-24, miRNA-29a and miRNA-502-
$3 p$ expression in PCOS subjects: correlation with biochemical parameters related to PCOS and insulin resistance. Indian J Clin Biochem. 2019;35:1691781.

44. Rashad NM, Ateya MA, Saraya YS, Elnagar WM, Helal KF, Lashin ME, Abdelrhman AA, Alil AE, Yousef MS. Association of miRNA - 320 expression level and its target gene endothelin-1 with the susceptibility and clinical features of polycystic ovary syndrome. J Ovarian Res. 2019;12:39.

45. Roth LW, McCallie B, Alvero R, Schoolcraft WB, Minjarez D, Katz-Jaffe MG. Altered microRNA and gene expression in the follicular fluid of women with polycystic ovary syndrome. J Assist Reprod Genet. 2014;31:355-62.

46. Yin M, Wang X, Yao G, Lu M, Liang M, Sun Y, Sun F. Transactivation of miR320 by miR-383 regulates granulosa cell functions by targeting E2F1 and SF-1*. J Biol Chem. 2014:289:18239-57.

47. Scalici E, Traver S, Mullet T, Molinari N, Ferrieres A, Brunet C, Belloc S, Hamamah S. Circulating microRNAs in follicular fluid, powerful tools to explore in vitro fertilization process. Sci Rep. 2016;6:24976.

48. Sorensen AE, Wissing ML, Englund AL, Dalgaard LT. MicroRNA species in follicular fluid associating with polycystic ovary syndrome and related intermediary phenotypes. J Clin Endocrinol Metab. 2016;101:1579-89.

49. Naji M, Aleyasin A, Nekoonam S, Arefian E, Mahdian R, Amidi F. Differential expression of miR-93 and miR-21 in granulosa cells and follicular fluid of polycystic ovary syndrome associating with different phenotypes. Sci Rep. 2017;7:14671.

50. Xue Y, Lv J, Xu P, Gu L, Cao J, Xu L, Xue K, Li Q. Identification of microRNAs and genes associated with hyperandrogenism in the follicular fluid of women with polycystic ovary syndrome. J Cell Biochem. 2018;119:3913-21.

51. Yao L, Li M, Hu J, Wang W, Gao M. MiRNA-335-5p negatively regulates granulosa cell proliferation via SGK3 in PCOS. Reproduction. 2018;156:439-49.

52. Zhang H, Gao ZN, Zhang YJ, Wang HH, Li YF. MiR-873-5p regulated LPSinduced oxidative stress via targeting heme oxygenase-1 (HO-1) in KGN cells. RSC Adv. 2018;8:39098-105.

53. Shi L, Liu S, Zhao W, Shi J. miR-483-5p and miR-486-5p are down-regulated in cumulus cells of metaphase II oocytes from women with polycystic ovary syndrome. Reprod BioMed Online. 2015;31:565-72.

54. Liu S, Zhang X, Shi C, Lin J, Chen G, Wu B, Wu L, Shi H, Yuan Y, Zhou W, et al. Altered microRNAs expression profiling in cumulus cells from patients with polycystic ovary syndrome. J Transl Med. 2015;13:238.

55. Xu B, Zhang YW, Tong XH, Liu YS. Characterization of microRNA profile in human cumulus granulosa cells: identification of microRNAs that regulate notch signaling and are associated with PCOS. Mol Cell Endocrinol. 2015;404:26-36.

56. Huang X, Liu C, Hao CF, Tang QQ, Liu RM, Lin SX, Zhang LP, Yan W. Identification of altered microRNAs and mRNAs in the cumulus cells of PCOS patients: miRNA-509-3p promotes oestradiol secretion by targeting MAP 3K8. Reproduction. 2016;151:643-55.

57. Cai G, Ma X, Chen B, Huang Y, Liu S, Yang H, Zou W. MicroRNA-145 negatively regulates cell proliferation through targeting IRS1 in isolated ovarian granulosa cells from patients with polycystic ovary syndrome. Reprod Sci. 2017;24:902-10.

58. Zhang CL, Wang H, Yan CY, Gao XF, Ling XJ. Deregulation of RUNX2 by miR-320a deficiency impairs steroidogenesis in cumulus granulosa cells from polycystic ovary syndrome (PCOS) patients. Biochem Biophys Res Commun. 2017:482:1469-76.

59. He T, Liu Y, Jia Y, Wang H, Yang X, Lu G, Liu H, Shi Y. MicroRNA-141 and MicroRNA-200c are overexpressed in granulosa cells of polycystic ovary syndrome patients. Front Med (Lausanne). 2018;5:299.

60. Mao Z, Fan L, Yu Q, Luo S, Wu X, Tang J, Kang G, Tang L. Abnormality of Klotho signaling is involved in polycystic ovary syndrome. Reprod Sci. 2018; 25:372-83.

61. Wang M, Sun J, Xu B, Chrusciel M, Gao J, Bazert M, Stelmaszewska J, Xu Y, Zhang $\mathrm{H}$, Pawelczyk $\mathrm{L}$, et al. Functional characterization of microRNA-27a-3p expression in human polycystic ovary syndrome. Endocrinology. 2018;159: 297-309.

62. Zhong Z, Li F, Li Y, Qin S, Wen C, Fu Y, Xiao Q. Inhibition of microRNA-19b promotes ovarian granulosa cell proliferation by targeting IGF-1 in polycystic ovary syndrome. Mol Med Rep. 2018;17:4889-98.

63. Geng Y, Sui C, Xun Y, Lai Q, Jin L. MiRNA-99a can regulate proliferation and apoptosis of human granulosa cells via targeting IGF-1R in polycystic ovary syndrome. Mol Hum Reprod. 2019;25:638-6.

64. Li Y, Xiang Y, Song Y, Wan L, Yu G, Tan L. Dysregulated miR-142, $-33 b$, and -423 in granulosa cells target TGFBR1 and SMAD7: a possible role in polycystic ovary syndrome. Mol Hum Reprod. 2019;25:638-46. 
65. Luo H, Han Y, Liu J, Zhang Y. Identification of microRNAs in granulosa cells from patients with different levels of ovarian reserve function and the potential regulatory function of miR-23a in granulosa cell apoptosis. Gene. 2019:686:250-60.

66. Wang Y, Xu S, Wang Y, Qi G, Hou Y, Sun C, Wu X. Identification and potential value of candidate microRNAs in granulosa cells of polycystic ovary syndrome. Technol Health Care. 2019;27:579-87.

67. Song Y, Yu G, Xiang Y, Li Y, Wan L, Tan L. Altered miR-186 and miR-135a contribute to granulosa cell dysfunction by targeting ESR2: A possible role in polycystic ovary syndrome. Mol Cell Endocrinol. 2019;494:110478.

68. Hou Y, Wang Y, Xu S, Qi G, Wu X. Bioinformatics identification of microRNAs involved in polycystic ovary syndrome based on microarray data. Mol Med Rep. 2019;20:281-91.

69. McCallie B, Schoolcraft WB, Katz-Jaffe MG. Aberration of blastocyst microRNA expression is associated with human infertility. Fertil Steril. 2010; 93:2374-82.

70. Wu HL, Heneidi S, Chuang TY, Diamond MP, Layman LC, Azziz R, Chen YH. The expression of the miR-25/93/106b family of micro-RNAs in the adipose tissue of women with polycystic ovary syndrome. J Clin Endocrinol Metab. 2014;99:E2754-61.

71. Xiang Y, Song Y, Li Y, Zhao D, Ma L, Tan L. miR-483 is Down-regulated in polycystic ovarian syndrome and inhibits KGN cell proliferation via targeting insulin-like growth factor 1 (IGF1). Med Sci Monit. 2016;22:3383-93.

72. Yuan WTL. MicroRNA-320 inhibits insulin resistance in patients with PCOS through regulating ERK1/2 signaling pathway. Biomed Res Int. 2017;28: 4946-9.

73. McAllister JM, Han AX, Modi BP, Teves ME, Mavodza GR, Anderson ZL, Shen T, Christenson LK, Archer KJ, Strauss JF. MicroRNA profiling reveals miRNA130b-3p mediates DENND1A variant 2 expression and androgen biosynthesis. Endocrinology. 2019;160:1964-81.

74. Kim SJ, Veenstra-VanderWeele J, Hanna GL, Gonen D, Leventhal BL, Cook EH Jr. Mutation screening of human 5-HT (2B) receptor gene in early-onset obsessive-compulsive disorder. Mol Cell Probes. 2000;14:47-52.

75. Vanderhyden BCAD. Role of cumulus cells and serum on the in vitro maturation, fertilization, and subsequent development of rat oocytes. Biol Reprod. 1989:40:720-8

76. Flynn RA, Chang HY. Long noncoding RNAs in cell-fate programming and reprogramming. Cell Stem Cell. 2014;14:752-61.

77. Quinn JJ, Chang HY. Unique features of long non-coding RNA biogenesis and function. Nat Rev Genet. 2016;17:47-62.

78. Nakagawa S, Shimada M, Yanaka K, Mito M, Arai T, Takahashi E, Fujita Y, Fujimori T, Standaert L, Marine JC, Hirose T. The IncRNA Neat1 is required for corpus luteum formation and the establishment of pregnancy in a subpopulation of mice. Development. 2014;141:4618-27.

79. Liu Z, Hao C, Song D, Zhang N, Bao H, Qu Q. Androgen receptor coregulator CTBP1-AS is associated with polycystic ovary syndrome in Chinese women: A preliminary study. Reprod Sci. 2015;22:829-37.

80. Liu ZT, Hao CF, Huang X, Zhang N, Bao HC, Qu QL. Peripheral blood leukocyte expression level of IncRNA steroid receptor RNA activator (SRA) and its association with polycystic ovary syndrome: a case control study. Gynecol Endocrinol. 2015;31:363-8.

81. Huang $X$, Hao CF, Bao HC, Wang MM, Dai HG. Aberrant expression of long noncoding RNAs in cumulus cells isolated from PCOS patients. J Assist Reprod Genet. 2016;33:111-21.

82. Liu YD, Li Y, Feng SX, Ye DS, Chen X, Zhou XY, Chen SL. Long noncoding RNAs: potential regulators involved in the pathogenesis of polycystic ovary syndrome. Endocrinology. 2017;158:3890-9.

83. Huang X, Pan J, Wu B, Teng X. Construction and analysis of a IncRNA (PWRN2)mediated ceRNA network reveal its potential roles in oocyte nuclear maturation of patients with PCOS. Reprod Biol Endocrinol. 2018;16:73.

84. Jiao J, Shi B, Wang T, Fang Y, Cao T, Zhou Y, Wang X, Li D. Characterization of long non-coding RNA and messenger RNA profiles in follicular fluid from mature and immature ovarian follicles of healthy women and women with polycystic ovary syndrome. Hum Reprod. 2018;33:1735-48.

85. Lin H, Xing W, Li Y, Xie Y, Tang X, Zhang Q. Downregulation of serum long noncoding RNA GAS5 may contribute to insulin resistance in PCOS patients. Gynecol Endocrinol. 2018;34:784-8.

86. Zhao J, Xu J, Wang W, Zhao H, Liu H, Liu X, Liu J, Sun Y, Dunaif A, Du Y, Chen ZJ. Long non-coding RNA LINC-01572:28 inhibits granulosa cell growth via a decrease in p27 (Kip1) degradation in patients with polycystic ovary syndrome. EBioMedicine. 2018;36:526-38.
87. Yang R, Chen J, Wang L, Deng A. LncRNA BANCR participates in polycystic ovary syndrome by promoting cell apoptosis. Mol Med Rep. 2019;19:1581-6.

88. Li Qin C-cH, Yan X-m, Wang Y, Zhong-yi, Wei X-c. Long non-coding RNA H19 is associated with polycystic ovary syndrome in Chinese women: a preliminary study. Endocr J. 2019;66:587-95.

89. Shan K, Liu C, Liu BH, Chen X, Dong R, Liu X, Zhang YY, Liu B, Zhang SJ, Wang JJ, et al. Circular noncoding RNA HIPK3 mediates retinal vascular dysfunction in diabetes mellitus. Circulation. 2017;136:1629-42.

90. Legnini I, Di Timoteo G, Rossi F, Morlando M, Briganti F, Sthandier O, Fatica A, Santini T, Andronache A, Wade M, et al. Circ-ZNF609 is a circular RNA that can be translated and functions in myogenesis. Mol Cell. 2017;66:22-37 e29.

91. Rybak-Wolf A, Stottmeister C, Glažar P, Jens M, Pino N, Giusti S, Hanan M, Behm M, Bartok O, Ashwal-Fluss R, et al. Circular RNAs in the mammalian brain are highly abundant, conserved, and dynamically expressed. Mol Cell. 2015;58:870-85.

92. Jeck WR, Sharpless NE. Detecting and characterizing circular RNAs. Nat Biotechnol. 2014;32:453-61.

93. Dang Y, Yan L, Hu B, Fan X, Ren Y, Li R, Lian Y, Yan J, Li Q, Zhang Y, et al. Tracing the expression of circular RNAs in human pre-implantation embryos. Genome Biol. 2016;17:130.

94. Cheng J, Huang J, Yuan S, Zhou S, Yan W, Shen W, Chen Y, Xia X, Luo A, Zhu D, Wang S. Circular RNA expression profiling of human granulosa cells during maternal aging reveals novel transcripts associated with assisted reproductive technology outcomes. PLoS One. 2017;12:e0177888.

95. Che Q, Liu M, Xu J, Liu Y, Cao X, Dong X, Liu S. Characterization of circular RNA expression profiles in cumulus cells from patients with polycystic ovary syndrome. Fertil Steril. 2019;111:1243-51.

96. Ma Z, Zhao H, Zhang Y, Liu X, Hao C. Novel circular RNA expression in the cumulus cells of patients with polycystic ovary syndrome; 2019.

97. Wang LP, Peng XY, Lv XQ, Liu L, Li XL, He X, Lv F, Pan Y, Wang L, Liu KF, Zhang XM. High throughput circRNAs sequencing profile of follicle fluid exosomes of polycystic ovary syndrome patients. J Cell Physiol. 2019;234: 15537-47.

98. Zhang C, Liu J, Lai M, Li J, Zhan J, Wen Q, Ma H. Circular RNA expression profiling of granulosa cells in women of reproductive age with polycystic ovary syndrome. Arch Gynecol Obstet. 2019;300:431-40.

99. Grunweller A, Hartmann RK. RNA interference as a gene-specific approach for molecular medicine. Curr Med Chem. 2005:12:3143-61.

100. Bumcrot D, Manoharan M, Koteliansky V, Sah DW. RNAi therapeutics: a potential new class of pharmaceutical drugs. Nat Chem Biol. 2006;2:711-9.

101. Anjali G, Kaur S, Lakra R, Taneja J, Kalsey GS, Nagendra A, Shrivastav TG, Devi MG, Malhotra N, Kriplani A, Singh R. FSH stimulates IRS-2 expression in human granulosa cells through CAMP/SP1, an inoperative FSH action in PCOS patients. Cell Signal. 2015;27:2452-66.

102. Li L, Mo H, Zhang J, Zhou Y, Peng X, Luo X. The role of heat shock protein $90 \mathrm{~B} 1$ in patients with polycystic ovary syndrome. PLoS One. 2016;11: e0152837.

103. Song WJ, Shi X, Zhang J, Chen L, Fu SX, Ding YL. Akt-mTOR signaling mediates abnormalities in the proliferation and apoptosis of ovarian granulosa cells in patients with polycystic ovary syndrome. Gynecol Obstet Investig. 2018;83:124-32.

104. Guan GZD, Zheng Y, Wen L, Yu D, Lu Y, Zhao Y. microRNA-423-3p promotes tumor progression via modulation of AdipoR2 in laryngeal carcinoma. Int J Clin Exp Pathol 75683-5691. 2014;7:1936-2625.

105. Wickham EP 3rd, Tao T, Nestler JE, McGee EA. Activation of the LH receptor up regulates the type 2 adiponectin receptor in human granulosa cells. J Assist Reprod Genet. 2013;30:963-8.

106. Comim FV, Hardy K, Franks S. Adiponectin and its receptors in the ovary: further evidence for a link between obesity and hyperandrogenism in polycystic ovary syndrome. PLoS One. 2013;8:e80416.

107. Carmina ER, F., Jannì A. Increased DHEAs levels in PCO syndrome: evidence for the existence of two subgroups of patients. J Endocrinol Investig. 1986;9:5-9.

108. Steinberger ES, Smith KD, Rodriguez-Rigau LJ. Testosterone, dehydroepiandrosterone, and dehydroepiandrosterone sulfate in hyperandrogenic women. J Clin Endocrinol Metab. 1984;59:471-7.

109. Hoffman DI, Klove K, Lobo RA. The prevalence and significance of elevated dehydroepiandrosterone sulfate levels in anovulatory women. Fertil Steril. 1984;42:76-81.

110. Apparao KBCL, Lovely LP, Gui Y, Lininger RA, Lessey BA. Elevated endometrial androgen receptor expression in women with polycystic ovarian syndrome. Biol Reprod. 2002;66:297-304. 
111. Hillier SG, Tetsuka M, Fraser HM. Location and developmental regulation of androgen receptor in primate ovary. Hum Reprod. 1997;12:107-11.

112. Sen A, Prizant H, Light A, Biswas A, Hayes E, Lee H-J, Barad D, Gleicher N, Hammes SR. Androgens regulate ovarian follicular development by increasing follicle stimulating hormone receptor and microRNA-125b expression. Proc Natl Acad Sci U S A. 2014;111:3008-13.

113. Leivonen SK, Makela R, Ostling P, Kohonen P, Haapa-Paananen S, Kleivi K, Enerly E, Aakula A, Hellstrom K, Sahlberg N, et al. Protein lysate microarray analysis to identify microRNAs regulating estrogen receptor signaling in breast cancer cell lines. Oncogene. 2009;28:3926-36.

114. Schomberg DW, Couse JF, Mukherjee A, Lubahn DB, Sar M, Mayo KE, Korach KS. Targeted disruption of the estrogen receptor-alpha gene in female mice: characterization of ovarian responses and phenotype in the adult. Endocrinology. 1999;140:2733-44.

115. Zhao JJ, Lin J, Yang H, Kong W, He L, Ma X, Coppola D, Cheng JQ. MicroRNA-221/222 negatively regulates estrogen receptor alpha and is associated with tamoxifen resistance in breast cancer. J Biol Chem. 2008; 283:31079-86

116. Leygue EDH, Watson PH, Murphy LC. Expression of the steroid receptor RNA activator in human breast tumors. Cancer Res. 1999;59:4190-3.

117. Lanz RB, Chua SS, Barron N, Soder BM, DeMayo F, O'Malley BW. Steroid receptor RNA activator stimulates proliferation as well as apoptosis in vivo. Mol Cell Biol. 2003;23:7163-76.

118. Zhao X, Patton JR, Davis SL, Florence B, Ames SJ, Spanjaard RA. Regulation of nuclear receptor activity by a pseudouridine synthase through posttranscriptional modification of steroid receptor RNA activator. Mol Cell. 2004;15:549-58.

119. Takayama K, Tsutsumi S, Katayama S, Okayama T, Horie-Inoue K, Ikeda K, Urano T, Kawazu C, Hasegawa A, Ikeo K, et al. Integration of cap analysis of gene expression and chromatin immunoprecipitation analysis on array reveals genome-wide androgen receptor signaling in prostate cancer cells. Oncogene. 2010;30:619-30.

120. Takayama KH-IK, Katayama S, et al. Androgen-responsive long noncoding RNA CTBP1-AS promotes prostate cancer. EMBO J. 2013;32:1665-80.

121. Ling HY, Ou HS, Feng SD, Zhang XY, Tuo QH, Chen LX, Zhu BY, Gao ZP, Tang CK, Yin WD, et al. CHANGES IN microRNA (miR) profile and effects of miR-320 in insulin-resistant 3T3-L1 adipocytes. Clin Exp Pharmacol Physiol. 2009;36:e32-9

122. Vendola KAZJ, Adesanya OO, Weil SJ, Bondy CA. Androgens stimulate early stages of follicular growth in the primate ovary. J Clin Invest. 1998;101: 2622-9.

123. Chen X, Zhao G, Wang F, Gao F, Luo H, Wang Y, Du Y, Chen X, Xue C, Dong Z, Song G. Upregulation of miR-513b inhibits cell proliferation, migration, and promotes apoptosis by targeting high mobility group-box 3 protein in gastric cancer. Tumour Biol. 2014;35:11081-9.

124. Stubbs SA, Stark J, Dilworth SM, Franks S, Hardy K. Abnormal preantral folliculogenesis in polycystic ovaries is associated with increased granulosa cell division. J Clin Endocrinol Metab. 2007:92:4418-26.

\section{Publisher's Note}

Springer Nature remains neutral with regard to jurisdictional claims in published maps and institutional affiliations.

Ready to submit your research? Choose BMC and benefit from:

- fast, convenient online submission

- thorough peer review by experienced researchers in your field

- rapid publication on acceptance

- support for research data, including large and complex data types

- gold Open Access which fosters wider collaboration and increased citations

- maximum visibility for your research: over $100 \mathrm{M}$ website views per year

At $\mathrm{BMC}$, research is always in progress.

Learn more biomedcentral.com/submissions 